$$
\text { UNIVERSIDADE DE BRASÍLIA - UNB }
$$

UNIVERSIDADE DE BRASÍLIA - UNB

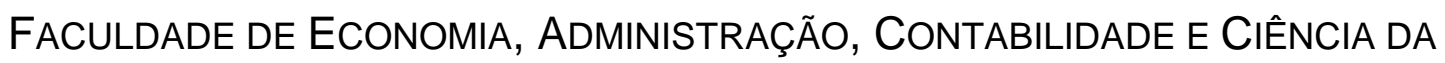
INFORMAÇÃO E DOCUMENTAÇÃO (FACE)

Programa de Pós-Graduação em Administração - PPGA

Neide Aparecida da Costa Durante Modrach

\title{
Movimentação de Recursos do Governo Federal em Moeda Estrangeira Uma Proposta de Incorporação aos Mecanismos da Conta Única
}




\section{Neide Aparecida da Costa Durante Modrach}

\section{Movimentação Recursos do Governo Federal em Moeda Estrangeira Uma Proposta de Incorporação aos Mecanismos da Conta Única}

Monografia apresentada ao Programa de PósGraduação em Administração (PPGA) da Faculdade de Economia, Administração, Contabilidade e Ciência da Informação e Documentação (FACE), da Universidade de Brasília, como requisito parcial à obtenção do grau de Especialista Lato Sensu em Orçamento e Finanças.

Orientador: Prof. Paulo Henrique Feijó

Brasília - DF 


\section{RESUMO}

É por meio do Sistema Integrado de Administração Financeira do Governo Federal (SIAFI) que a Secretaria do Tesouro Nacional (STN) controla a movimentação da Conta Única do Tesouro Nacional. A Conta Única é o mecanismo que permite a movimentação de recursos financeiros dos Órgãos e Entidades ligadas ao SIAFI em conta bancária unificada. A Conta Única é mantida pelo Banco Central do Brasil (BACEN) e destina-se a acolher, em conformidade com o disposto no $\S 3^{\circ}$ do artigo 164 da Constituição Federal, as disponibilidades financeiras da União.

Palavras-chaves: Conta Única. SIAFI. Execução em Moeda Estrangeira. Ordem Bancária. Tesouro Nacional. 


\section{LISTA DE FIGURAS}

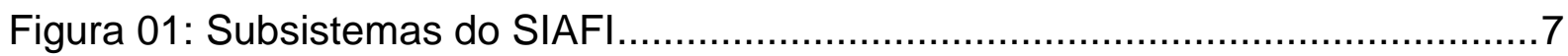

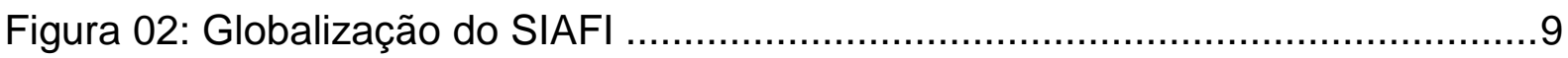

Figura 03: Conta Única - Documentos de Sensibilização de Saldo .........................11

Figura 04: Conta Única - Ingressos e Saídas de Recursos.....................................12

Figura 05: Evolução do SIAFI no Tempo …………….................................16

Figura 06 - Ciclo de Gestão e Competências...................................................19

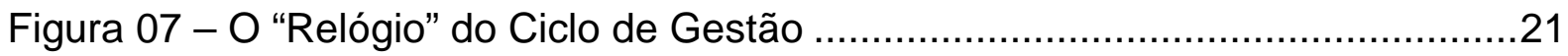

Figura 08 - Descentralização de Créditos x Movimentação de Recursos .................22

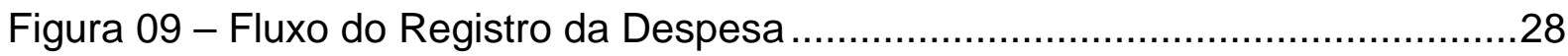

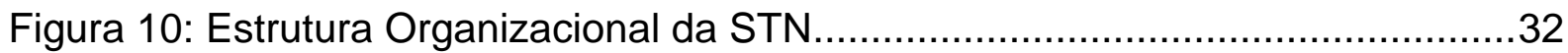

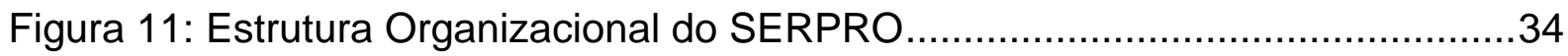

Figura 12: Esquema de Liberação de Financeiro ..................................................45

\section{LISTA DE TABELAS}

Tabela 01 - Órgão x Unidades Gestoras x Usuários Cadastrados.............................

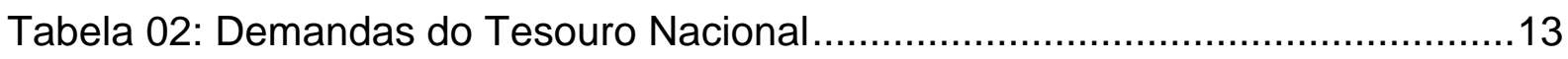

Tabela 03 - Tipos de Ordens Bancárias x Agente Financeiro .................................25

Tabela 04 - Situação de resposta ao questionário aplicado .....................................37

Tabela 05 - Tipos de Ordens Bancárias x Agente Financeiro ..................................38 


\section{LISTA DE SIGLAS}

\begin{tabular}{ll} 
BACEN & - Banco Central do Brasil \\
BB & - Banco do Brasil \\
CAF & - Coordenação de Assuntos Fiscais \\
CEF & - Caixa Econômica Federal \\
CMO & - Comissão Mista de Orçamentos \\
CONORF & - Consultoria de Orçamentos do Senado \\
COFF & - Consultoria de Orçamentos da Câmara \\
COSIS & - Coordenação Geral de Sistemas \\
CPGF & - Cartão de Pagamentos do Governo Federal \\
CPR & - Contas a Pagar e Receber \\
DAR & - Documento de Arrecadação Federal \\
DD & - Depósito Direto \\
DEST & - Departamento das Estatais \\
FPE & - Fundo de Participação de Estados \\
FPM & - Fundo de Participação de Municípios \\
GPS & - Guia de Recolhimento do INSS \\
GRU & - Guia de Recolhimento da União \\
INSS & - Instituto de Seguridade Social \\
LDO & - Lei de Diretrizes Orçamentárias \\
LOA & - Lei de Orçamento Anual \\
MF & - Ministério da Fazenda \\
NBCASP & - Normas Brasileiras de Contabilidade Aplicadas ao Setor Público \\
NE & - Nota de Empenho \\
NICSP & - Normas Internacionais de Contabilidade Aplicadas ao Setor Público \\
NL & - Nota de Lançamento \\
OB & - Ordem Bancária \\
OBA & - Ordem Bancária de Aplicação no Banco do Brasil \\
OBB & - Ordem Bancária com favorecido Banco \\
OBC & - Ordem Bancária para crédito em conta corrente \\
OBD & - Ordem Bancária de Fatura \\
OBF & - Ordem Bancária de Folha de Pagamento \\
OBH & - Ordem Bancária de Processo Judicial \\
OBJ & - Ordem Bancária Judicial \\
\hline SE &
\end{tabular}




$\begin{array}{ll}\text { OBK } & \text { - Ordem Bancária de Câmbio } \\ \text { OBP } & \text { - Ordem Bancária de Pagamento } \\ \text { OBR } & \text { - Ordem Bancária de Reserva e BACEN } \\ \text { OBS } & \text { - Ordem Bancária de Cancelamento } \\ \text { OBSPB } & \text { - Ordem Bancária de Crédito em Conta Corrente via Sistema de } \\ & \text { Pagamentos Brasileiro } \\ \text { OBSTN } & \text { - Ordem Bancária de Operações Secretaria do Tesouro Nacional } \\ \text { OSPF } & \text { - Órgão Setorial de Programação Financeira } \\ \text { PGFN } & \text { - Procuradoria Geral da Fazenda Nacional } \\ \text { PPA } & \text { - Plano Plurianual } \\ \text { SERPRO } & \text { - Serviço Federal de Processamento de Dados } \\ \text { SIAFI } & \text { - Sistema Integrado de Administração Financeira } \\ \text { SISBACEN } & \text { - Sistema de Informações do Banco Central } \\ \text { SOF } & \text { - Secretaria de Orçamento Federal } \\ \text { SPB } & \text { - Sistema de Pagamentos Brasileiro } \\ \text { SPE } & \text { - Secretaria de Política Econômica } \\ \text { SPI } & - \text { Secretaria de Investimentos e Planejamento Estratégico } \\ \text { SRF } & \text { - Secretaria da Receita Federal } \\ \text { STN } & - \text { Secretaria do Tesouro Nacional } \\ \text { SUNAF } & - \text { Superintendência de Negócio Administração Financeira } \\ \text { TI } & - \text { Tecnologia da Informação } \\ \text { TIC } & - \text { Tecnologia da Informação e Comunicação } \\ \text { TN } & - \text { Tesouro Nacional }\end{array}$




\section{SUMÁRIO}

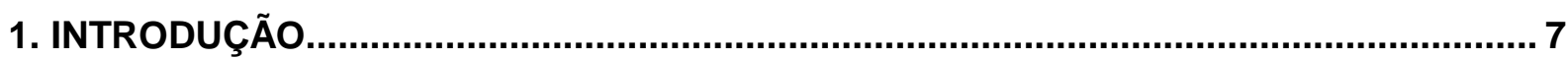

2. FUNDAMENTAÇÃO TEÓRICA ….........................................................................

2.1. Sistema Integrado de administração Financeira da União..................................... 10

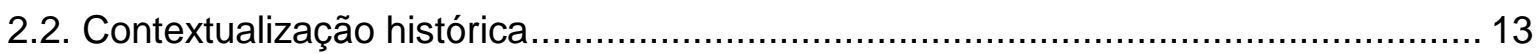

2.3. A evolução Sistema Integrado de administração Financeira da União ..................... 15

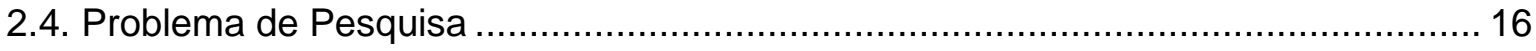

2.5. O ciclo orçamentário e financeiro ................................................................ 18

2.6. A Conta Única do Tesouro Nacional ................................................................. 25

2.7. O processo em Real e em Moeda Estrangeira................................................. 28

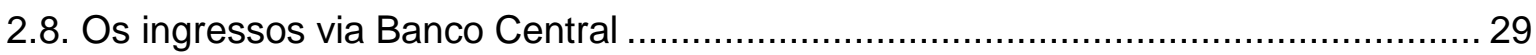

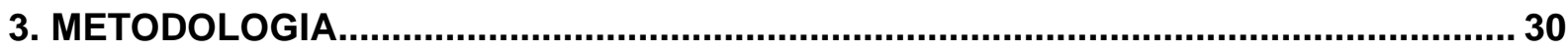

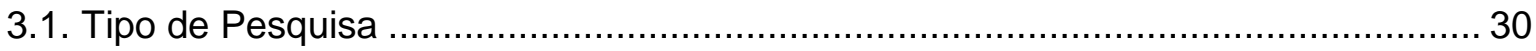

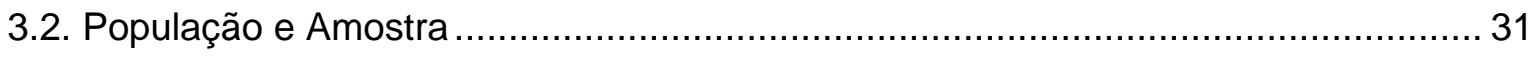

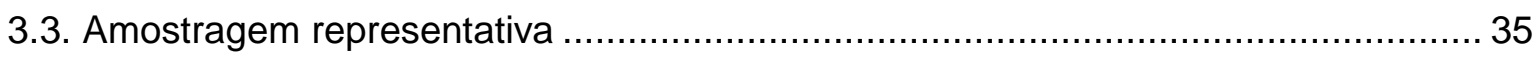

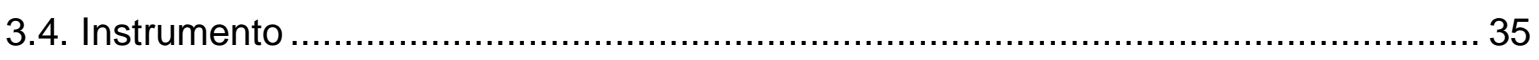

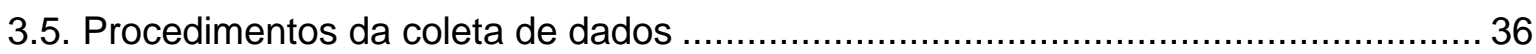

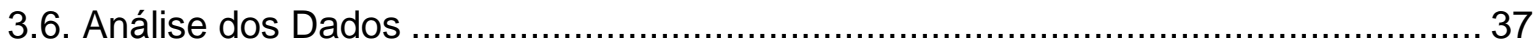

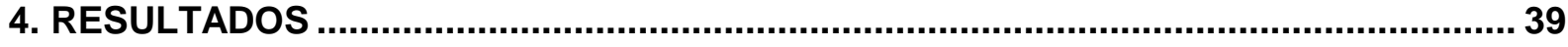

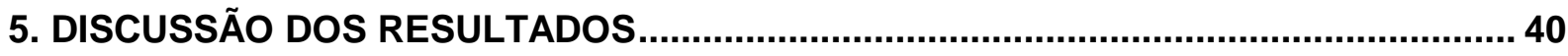

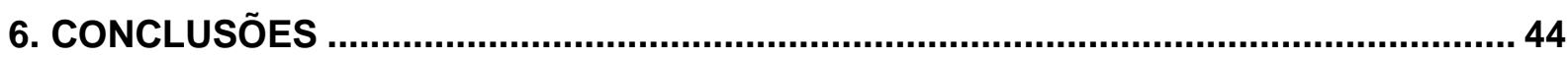

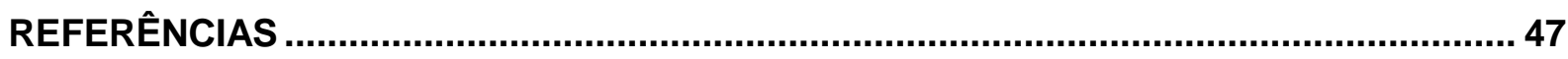

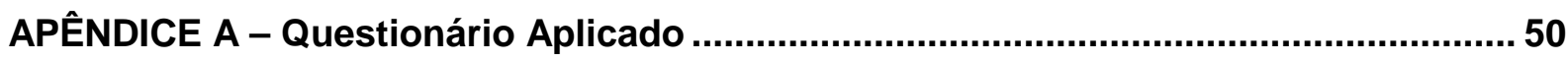

APÊNDICE B - Objetivos do Questionário Aplicado.................................................... 51

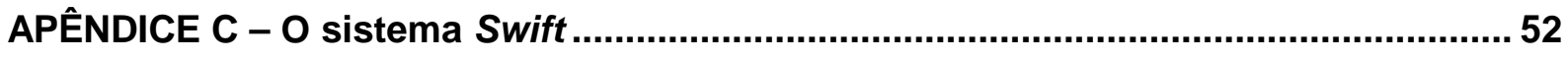

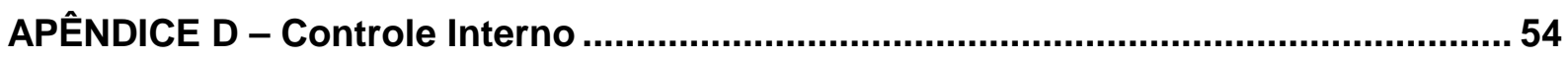

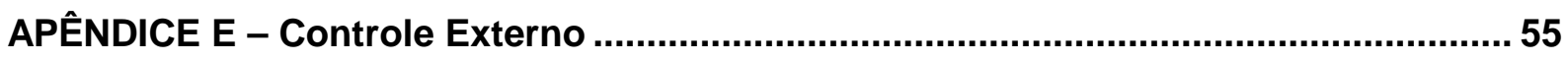

APÊNDICE F - A elaboração e a execução dos orçamentos públicos ..........................56

ANEXO A - Artigo “A cultura do poço sem fundo" ........................................................ 60 


\section{INTRODUÇÃO}

O Sistema Integrado de Administração Financeira do Governo Federal (SIAFI) é o instrumento para o acompanhamento e controle da execução orçamentária, financeira e contábil do Governo Federal. Configura-se num dos maiores, mais complexo e mais abrangente instrumento de administração das finanças públicas.

Desde a sua implantação em 1987 o Governo Federal e a Secretaria do Tesouro Nacional têm buscado medidas para a melhoria da ferramenta e aprimoramento da utilização dos recursos do Governo Federal.

O SIAFI engloba funcionalidades das mais diversas, que permitem ao Governo Federal, realizar as despesas previstas no orçamento, em conformidade aos três estágios da execução da despesa previstos na Lei no. 4320 (BRASIL, 1964): empenho, liquidação e pagamento. A Figura 01 mostra o conjunto de sistemas que compõem o SIAFI.

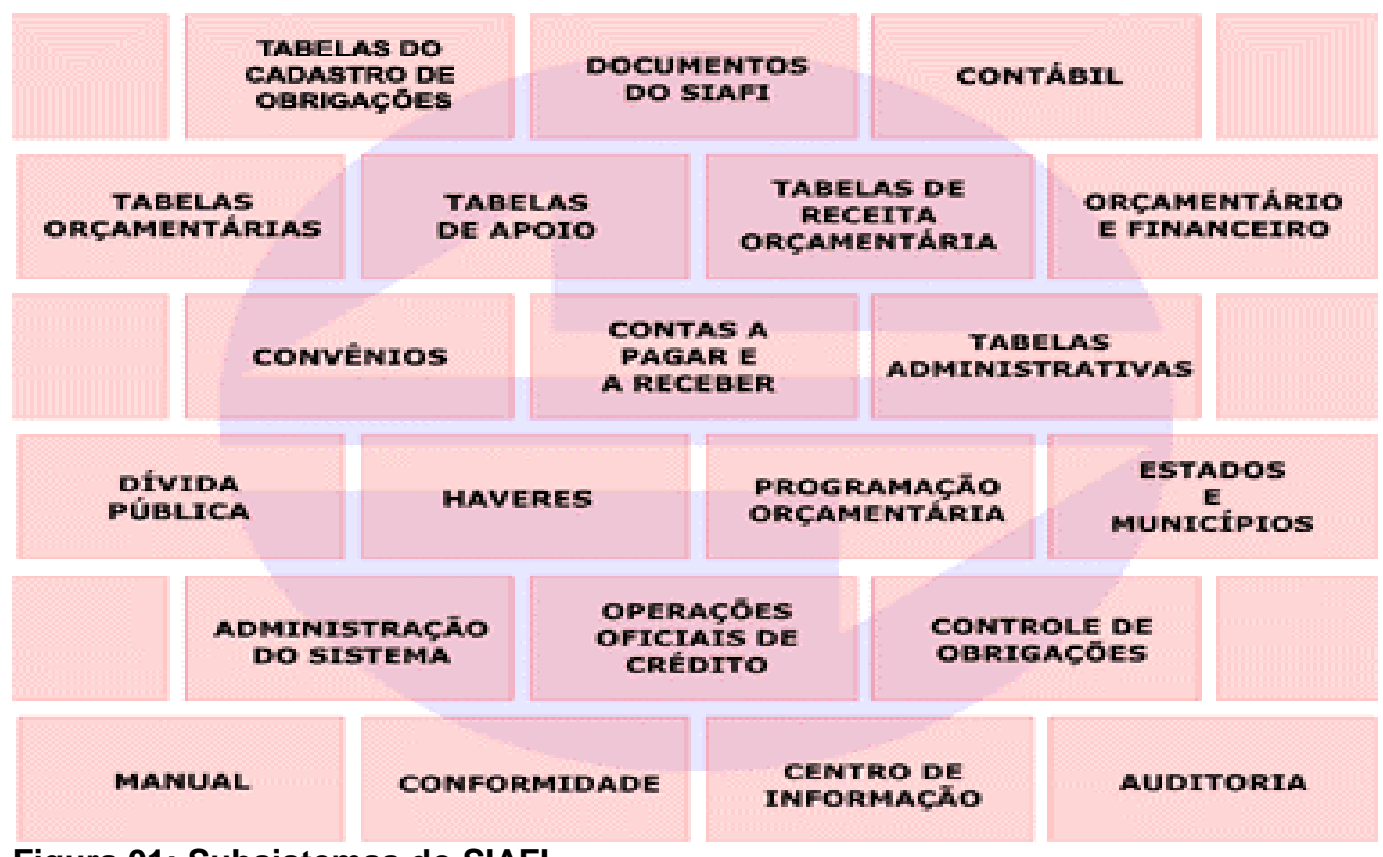

Figura 01: Subsistemas do SIAFI

Fonte: Sítio do Tesouro Nacional (2009)

São funcionalidades do SIAFI os diversos tipos de pagamentos, os repasses 
de verbas referentes aos Fundos de Participação dos Municípios e Estados ${ }^{1}$ (FPM e FPE), os repasses de transferências voluntárias, tais como Convênios e Contratos de Parceria, a gestão da dívida externa, a contabilidade propriamente dita, dentre outras.

A Tabela 01 demonstra, apenas nos últimos seis anos, a expansão crescente do sistema. Esse comportamento é o mesmo desde sua criação.

\begin{tabular}{|c|c|c|c|c|c|c|}
\hline & 2008 & 2007 & 2006 & 2005 & 2004 & 2003 \\
\hline Quantidade de Órgãos & 468 & 455 & 449 & 445 & 428 & 370 \\
\hline Quantidade de Unidades Gestoras & 20.015 & 17.711 & 17.915 & 17.874 & 17.233 & 14.564 \\
\hline Executoras & 8.721 & 8.678 & 8.597 & 6.342 & 6.138 & 4.784 \\
\hline Credoras & 7.339 & 6.008 & 6.250 & 8.624 & 8.678 & 7.448 \\
\hline Controle & 3.955 & 3.025 & 3.068 & 2.908 & 2.417 & 2.332 \\
\hline Quantidade de Usuários Ativos & 59.009 & 56.203 & 53.241 & 50.634 & 42.137 & 35.384 \\
\hline
\end{tabular}

Tabela 01 - Órgão x Unidades Gestoras x Usuários Cadastrados

Fonte: http://consulta.tesouro.fazenda.gov.br/Estatisticas/index_estatistica_uso.asp

O SIAFI é utilizado, atualmente, por todos os Órgãos da Administração Direta $^{2}$ (Poderes Legislativo, Executivo e Judiciário) e por grande parte da Administração Indireta ${ }^{3}$ do Governo Federal. Destacam-se nesse contexto, instituições de ensino profissionalizante de contabilidade $\left(2^{\circ}\right.$ e 3 graus e de pósgraduação) que utilizam os recursos do ambiente de treinamento do SIAFI (SIAFI Educacional) para o desenvolvimento de disciplinas afins. Além desses usuários diretos do ambiente SIAFI, outros interessados podem também ter acesso às informações geradas pelo sistema, tais como os institutos de pesquisas econômico-

1 Transferências a Estados e Municípios - compreende as transferências constitucionais, resultantes da Lei Complementar ํㅜ 87/96, e outras transferências. As transferências constitucionais originam-se do Imposto de Renda (IR)e do Imposto sobre Produtos Industrializados (IPI), cobrados pelo governo federal, e transferido aos estados e municípios através dos fundos.

2 Representa o conjunto de Órgãos que respondem pelos serviços integrados na estrutura administrativa da Presidência da República e dos Ministérios (art. 4ํㅡ, inciso I, do Decreto-lei nํㅡㄹ 200, de 25 de fevereiro de 1967).

3 Compreende as seguintes categorias de entidades, dotadas de personalidade jurídica própria;

a) Autarquias;

b) Empresas Públicas;

c) Sociedade de Economia Mista.

d) Fundações Públicas 
financeiras, comissões e assessorias, parlamentares, órgãos de controle interno e externo e outros órgãos governamentais. A Figura 02 demonstra a abrangência global do sistema, que também é utilizado pelas Embaixadas e outros Órgãos no exterior.

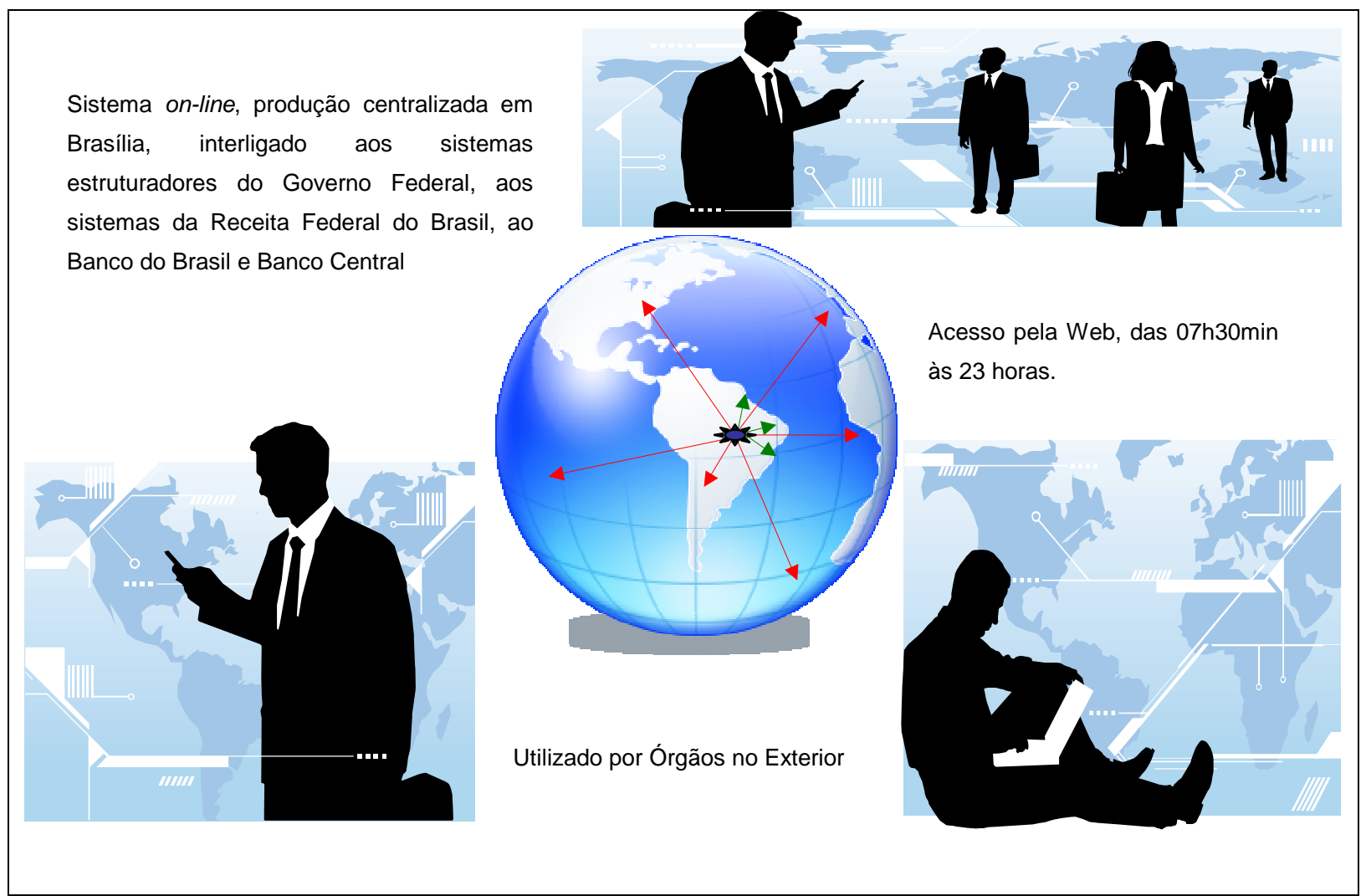

Figura 02: Globalização do SIAFI

Fonte: Autora (2009) 


\section{FUNDAMENTAÇÃO TEÓRICA}

\subsection{SISTEMA INTEGRADO DE ADMINISTRAÇÃO FINANCEIRA DA UNIÃO}

É por meio do SIAFI que a STN controla a movimentação da Conta Única do Tesouro Nacional, implantada em 1988, e efetua a sua conciliação diária.

A Conta Única apresenta-se como um marco na administração financeira dos recursos públicos no Governo Federal. É o mecanismo que permite a movimentação de recursos dos Órgãos e Entidades ligadas ao SIAFI em conta bancária unificada. Esta unificação, além de garantir a manutenção da autonomia e individualização, permite o controle imediato dos gastos sobre suas disponibilidades financeiras.

A Conciliação da Conta Única consiste basicamente na rotina de compatibilização diária dos lançamentos contábeis efetuados no SIAFI com a movimentação ocorrida no Sistema de Informações do BACEN (SISBACEN), que fornece o Extrato de Depósito do Governo Federal da Conta Única para a STN. Esse processo é automático e faz parte do escopo do sistema SIAFI.

A Conta Única é mantida junto ao Banco Central do Brasil (BACEN), destina-se a acolher, em conformidade com o disposto no $\S 3^{\circ}$ do artigo 164 da Constituição Federal, as disponibilidades financeiras da União que se encontram à disposição das Unidades Gestoras, nos limites financeiros previamente definidos.

Assim, o BACEN exerce a função de "banqueiro" do governo, detendo a chamada Conta Única do Tesouro Nacional. Essas disponibilidades são compostas por recursos de origem tributária e não tributária, recolhidos pelas instituições financeiras na função de intermediárias na arrecadação de tributos e pagamentos à ordem do Tesouro Nacional, pelo resultado líquido dos leilões primários do Tesouro Nacional e pelo resultado positivo do BACEN. Este último destina-se ao resgate de dívida do Tesouro Nacional.

O ingresso de recursos se dá quando o contribuinte efetua o pagamento de seus tributos.

A Figura 03 demonstra os documentos que realizam movimentação na Conta Única. Os ingressos de recursos ocorrem a partir dos documentos SIAFI para Arrecadação (DAR), Guia da Previdência Social (GPS) e Guia de Recolhimento da 
União. A saída de recursos somente ocorre por meio de Ordem Bancária. Mais a frente são explorados os tipos de Ordem Bancária, que estão associados ao tipo de pagamento que está sendo efetuado, como por exemplo, diretamente numa conta corrente, para pagamento de faturas, entre outros.

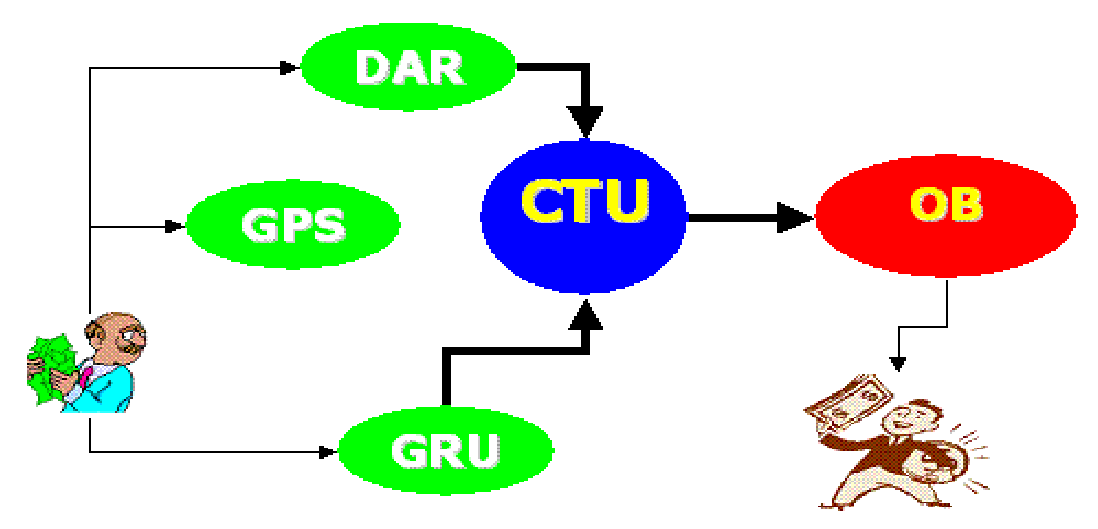

Figura 03: Conta Única - Documentos de Sensibilização de Saldo Fonte: FEIJÓ (2008)

A Figura 04 demonstra os tipos de ingressos e saídas da Conta Única no BACEN. A alimentação de recursos à Conta Única ocorre por meio da realização de receitas, incluindo aquelas oriundas de arrecadação do Instituto Nacional de Seguridade Social (INSS), bem como da Emissão de Títulos. Já a saída de recursos, conforme mencionado anteriormente, ocorre por meio da emissão de mensagens do SPB, ou por Ordem Bancária via SPB ou BB. Por fim, é importante registrar que os valores são "carimbados" na Conta Única, nas subcontas referentes ao Tesouro Nacional, Previdência Social e Dívidas. 


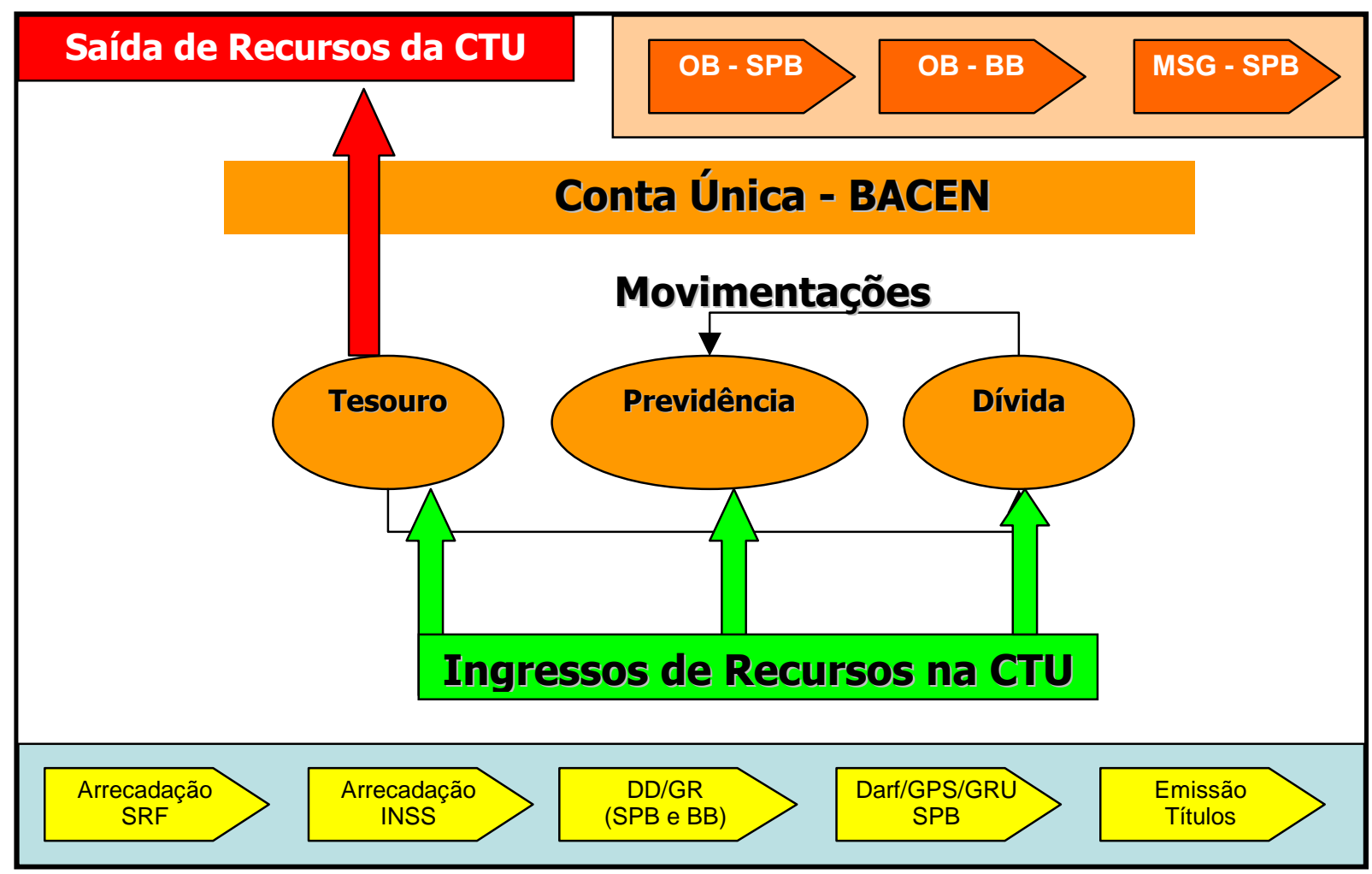

Figura 04: Conta Única - Ingressos e Saídas de Recursos Fonte: FEIJÓ (2008)

A movimentação da conta ocorre por meio de documentos do sistema, sendo o Banco do Brasil (BB) o principal Agente Financeiro responsável pelos pagamentos e recebimentos, conforme estabelecido na IN STN 04/2004. Em situações especiais podem ser utilizados outros agentes financeiros, desde que autorizados pelo Ministério da Fazenda. Atualmente o Tesouro Nacional integra ao Sistema de Pagamentos Brasileiro ${ }^{4}$ (SPB) para transferências diretas às instituições financeiras.

Embora tenham ocorrido evoluções no mecanismo da Conta Única, ao longo dos últimos vinte anos, este ainda apresenta possibilidades de evolução.

É nesse contexto de evoluções constantes do SIAFI e diante da necessidade sempre presente da transparência e do registro do Ato e do Fato (no

4 Sistema de Pagamentos é o conjunto de procedimentos, regras, instrumentos e operações integradas que permitem a movimentação financeira na economia de mercado, tanto em moeda local quanto estrangeira, em situações de câmbio. Sua função básica é permitir a transferência de recursos, o processamento e a liquidação de pagamentos para pessoas físicas, empresas e governos e garantir segurança ao mercado financeiro do País, oferecendo maior proteção a toda e qualquer transferência de recursos. É um esforço para se reduzir riscos, o que gera tranqüilidade para toda a economia, contribuindo para a melhoria da classificação do Brasil nas análises internacionais de risco. 
momento em que ocorrem) que se insere esse trabalho, com a proposta de apresentar contribuições ao Governo Federal de melhorias no processo vigente e nas ferramentas utilizadas a partir da analise da situação atual, considerando o uso da Tecnologia da Informação (TI) que é um dos componentes mais importantes da atualidade.

As organizações brasileiras têm utilizado ampla e intensamente essa tecnologia, tanto em nível operacional como estratégico (ALBERTIN, 2008, p276). Embora não tenham sido identificadas estatísticas claras sobre os gastos do governo federal do Brasil em TI, é possível que o Brasil seja o país que mais investe em TI entre os países em desenvolvimento (RODRIGUES FILHO; GOMES, 2004, p.95), essa é uma percepção comprovada no caso do SIAFI, que apresenta nos últimos dez anos, mais de doze mil melhorias. A Tabela 02 demonstra a quantidade de demandas por exercício.

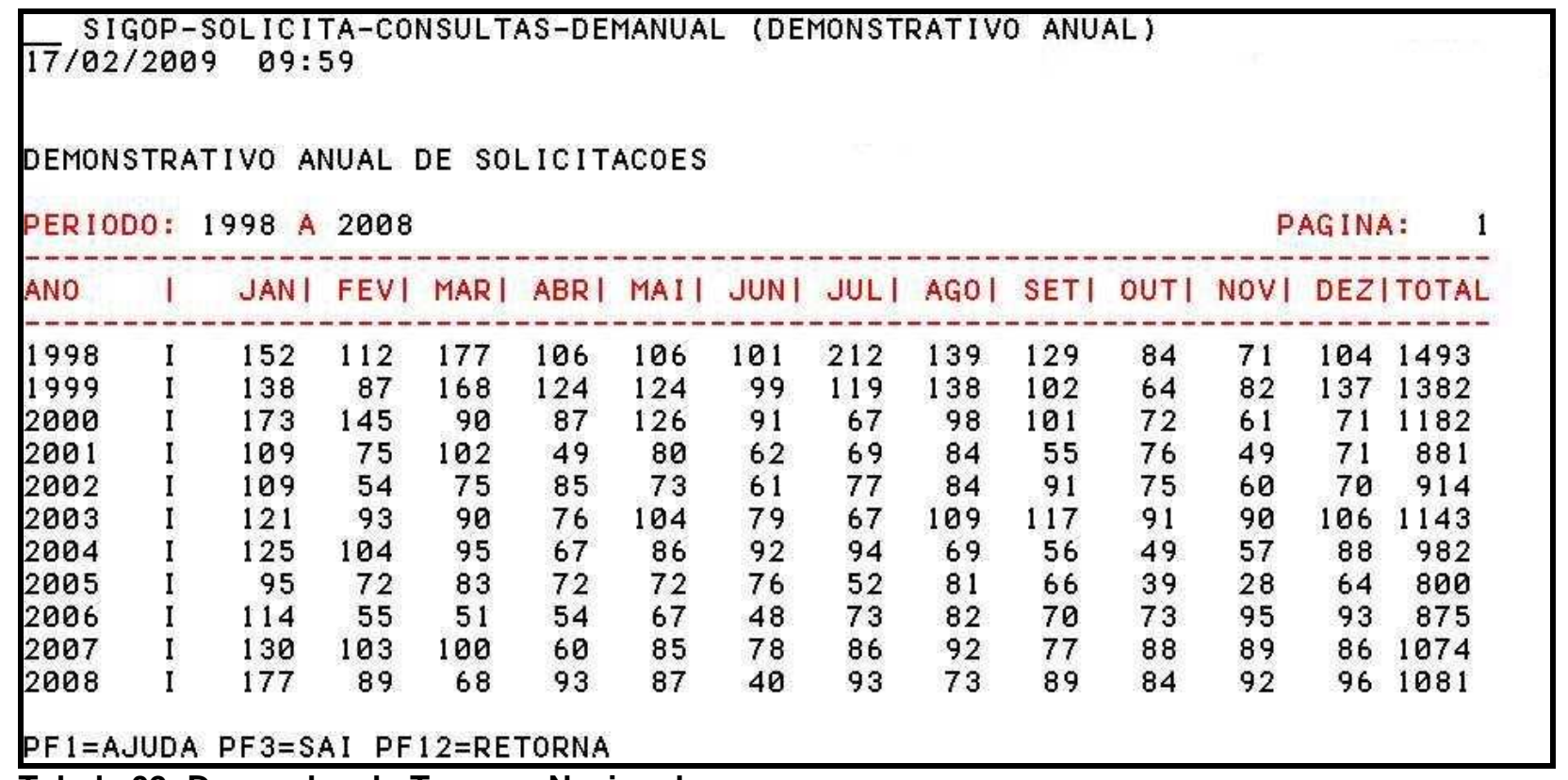

Tabela 02: Demandas do Tesouro Nacional

Fonte: Sistema de Gestão de Demandas da STN (2009)

\subsection{CONTEXTUALIZAÇÃO HISTÓRICA}

A STN foi criada pelo Decreto $n .092 .452$ (BRASIL, 1986) com a função de Órgão Central do sistema de administração financeira, contabilidade e auditoria do 
Governo Federal. O Decreto n. 993.874 (BRASIL, 1986) estabeleceu o controle interno do Poder Executivo e as normas de execução orçamentária da União.

Em 1986 inicia-se o desenvolvimento do SIAFI e em 1987 é implantada a primeira versão do sistema. Quando a Constituição de 1988 foi promulgada, já encontrou a mecânica disponível e pronta para a Conta Única.

Desde então, o Governo Federal e a STN têm buscado medidas para a otimização da utilização dos recursos, conforme retratam Castro e Garcia:

[...] A idéia da Conta Única surgiu quando se definiu como diretriz do SIAFI que cada gestor teria um terminal ou teria acesso a um terminal, ligado diretamente a Brasília e dentro de um único sistema operacional e contábil. Como todos estariam interligados, os pagamentos entre eles não precisariam passar pela rede bancária. (CASTRO;GARCIA,2004,p.124)

Este é um outro fato importante. Como as unidades estavam interligadas, não era necessário que as movimentações financeiras entre as unidades usuárias do SIAFI passassem pelo mercado financeiro. Dessa forma os pagamentos chamados "Intra-SIAFI" tornaram-se apenas registros contábeis, sem obrigar que o recurso financeiro (o dinheiro) passasse pelo mercado. Era como tirar dinheiro de um bolso para outro, sem passar por um terceiro, um banco qualquer.

Foram várias as mudanças promovidas no Governo Federal. A razão de ser delas e o impacto provocado está sintetizado no artigo "A cultura do poço sem fundo", publicado no jornal "a Folha de São Paulo" em 25 de junho de 1993, onde o ex-presidente José Sarney, apresenta um resumo do que foi a reformulação iniciada em seu governo das finanças públicas.

No referido texto destaca-se a dificuldade de calcular 0 déficit e conseqüente avaliação com o mínimo de margem de segurança para o estabelecimento da despesa. À época o Tesouro Nacional era uma entidade abstrata, sem automação e controles em tempo real. Não era possível ao Ministério da Fazenda avaliar a necessidade de liberação de recursos e o gasto das parcelas anteriormente liberadas. Existiam milhares de contas espalhadas pelo país, que pulverizavam os recursos públicos. Ainda no texto, o ex-presidente da república, destaca:

[...] O exótico relacionamento do Tesouro com o Banco do Brasil (Conta de Movimento, que acabamos) e o Banco Central não permitia nenhuma transparência. Esses bancos executavam operações de caráter eminentemente fiscal, programas de fomento, colocação e resgate de títulos 
da dívida mobiliária etc. Era o Banco do Brasil a autoridade monetária e banco comercial. Essas operações constituam o chamado Orçamento Monetário, que corria por fora. [...] (SARNEY, 1993)

\subsection{A EVOLUÇÃO SISTEMA INTEGRADO DE ADMINISTRAÇÃO FINANCEIRA DA UNIÃO}

Ao longo dos anos o SIAFI apresenta inovações, dentre as quais se destacam:

- Em setembro de 1988, a criação da Conta Única, quando foi extinta a maioria das contas bancárias das unidades;

- Em julho de 1998 foi criada a sistemática de depósito direto da Conta Única, possibilitando a extinção das contas tipo "C";

- Em outubro de 1998 foram incorporados os recursos do Instituto Nacional de Seguridade Social - INSS aos mecanismos da Conta Única, com a criação da CTU - INSS;

- Em janeiro de 1999, iniciou-se a aplicação financeira na Conta Única;

- Em maio de 2000, foi criada a Ordem Bancária de Movimentação de Reservas Bancárias (OBR), que inaugurou a realização de movimentações financeiras diretamente com o BACEN por meio da interligação entre o SIAFI e o SISBACEN;

- Em 2001, a implantação do Cartão de Pagamento do Governo Federal (CPGF) e da modalidade de saque à Conta Única por meio de Cartão de Crédito e conseqüente extinção das contas para suprimento de fundos;

- Em abril de 2002 a integração do SIAFI ao Sistema Brasileiro de Pagamentos (SPB);

- Em 2003 a implantação da Guia de Recolhimento da União (GRU)

- Em 2004 a institucionalização do Subsistema de Contas a Pagar e Receber do Governo Federal (CPR);

- Em 2008 a implantação do Documento Folha de Pagamento;

- Atualmente estuda-se a criação do Sistema de Custos do Governo Federal, onde novamente o SIAFI apresenta papel de destaque em função das 
informações registradas no sistema.

A Figura 05 sintetiza essa evolução e apresenta as principais evoluções programadas para os próximos três anos, como a implantação do Novo SIAFI Módulo Contas a Pagar e Receber, introdução das Normas Brasileiras de Contabilidade Aplicadas ao Setor Público (NBCASP) e as Normas Internacionais de Contabilidade do Setor Público (NICSP).

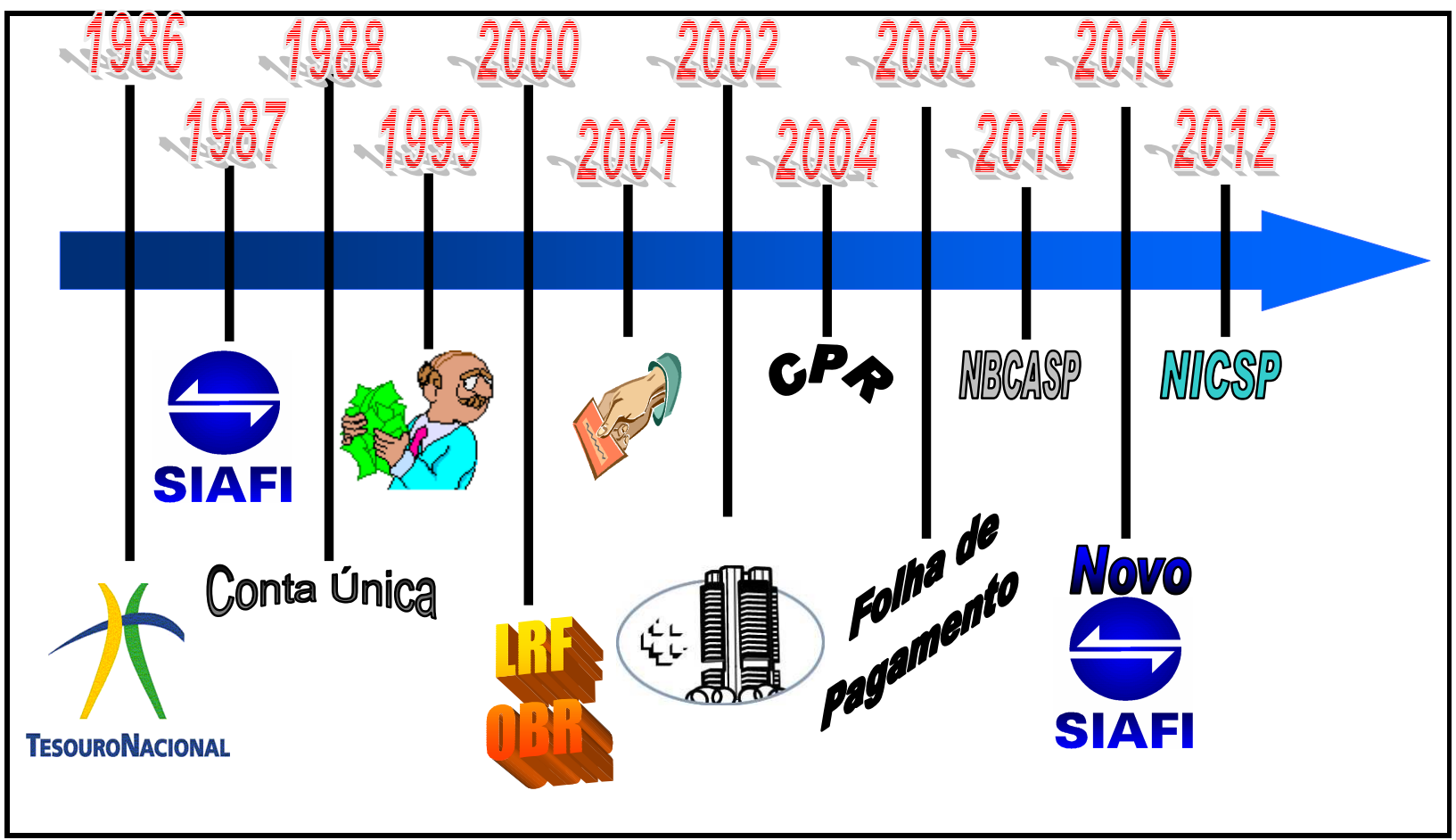

Figura 05: Evolução do SIAFI no Tempo

Fonte: Autora (2009)

\subsection{PROBLEMA DE PESQUISA}

Os benefícios oferecidos pela sistematização quanto à disponibilidade de informações e tempestividade que se apresentam, a visão de valor e a dimensão de negócio alcançada, fez o SIAFI cruzar as fronteiras do Brasil. Vários países demonstram grande interesse na filosofia do SIAFI, sendo que espécies do sistema já se acham implantados e ativados em algumas nações da América do Sul, da Europa e África.

A literatura sobre o assunto é escassa nos meios acadêmicos e de pesquisa, porém muito presente na legislação e nos procedimentos da Secretaria do 
Tesouro Nacional (STN).

Neste contexto, o estudo ora apresentado objetiva tratar a adoção da sistemática de Conta Única para os recursos em moeda estrangeira pode contribuir para visibilidade das disponibilidades dos recursos da União em outras moedas, permitindo adequação dos procedimentos para atendimento ao disposto na legislação, nas instruções normativas e nos procedimentos formais. Assim, foram avaliadas as seguintes questões:

- Avaliar a legislação que suporta a Conta Única e sua aderência para acomodar mecanismos que permitam a implantação de outras moedas;

- Descrever o funcionamento do mecanismo Conta Única do TN;

- Identificar os recursos que não estão inseridos nessa filosofia;

- Verificar a aderência do SIAFI na implantação de mecanismo de gestão das disponibilidades em moeda estrangeira;

- Identificar as possibilidades de modificações no SIAFI (e outros sistemas) visando à ampliação do mecanismo da Conta Única de forma que propicie uma visão integrada das disponibilidades de recursos e o registro dos Atos e Fatos no momento de sua ocorrência.

Pretende-se apresentar contribuições ao Governo Federal na medida em que, a partir da analise da situação atual, o trabalho visa propor melhorias no processo vigente e nas ferramentas utilizadas.

Quanto ao meio acadêmico, por ser uma pesquisa exploratória, poderá contribuir para desenvolver, esclarecer e modificar conceitos e idéias para a formulação de abordagens posteriores. Segundo Clemente (2007 apud GIL, 1999, p. 43), "este tipo de estudo visa proporcionar um maior conhecimento para o pesquisador acerca do assunto, a fim de que esse possa formular problemas mais precisos ou criar hipóteses que possam ser pesquisadas por estudos posteriores."

Quanto à Sociedade, é dever do Estado aperfeiçoar a programação financeira do Tesouro Nacional, gerenciar a Conta Única, avaliar os gastos governamentais e estabelecer normas sobre a execução orçamentária, financeira e contábil, bem como buscar permanentemente a transparência, o que pode ser fonte inspiradora da adoção de métodos para permitir maior transparência e controle pela sociedade. 


\subsection{O CICLO ORÇAMENTÁRIO E FINANCEIRO}

O Decreto-Lei № 200 (BRASIL, 1967), que promoveu a organização da Administração Federal e estabeleceu as diretrizes para Reforma Administrativa, determinou a implementação da unificação dos recursos movimentados pelo Tesouro Nacional para garantir maior economia operacional e a racionalização dos procedimentos relativos a execução da programação financeira de desembolso. $O$ princípio da unidade de caixa descrito no Artigo 56 da Lei 4.320 (BRASIL, 1964) define que o recolhimento de todas as receitas far-se-á em estrita observância ao princípio de unidade de tesouraria, vedada qualquer fragmentação para criação de caixas especiais.

As regras dispondo sobre a unificação dos recursos do Tesouro Nacional foram estabelecidas pelo Decreto №. 93.872 (BRASIL, 1986). No entanto, a determinação legal só foi cumprida com a promulgação da Constituição de 1988, quando todas as disponibilidades do Tesouro Nacional, em moeda nacional existentes nos diversos agentes financeiros, foram transferidas para o Banco Central do Brasil, em Conta Única centralizada.

O processo orçamentário do Governo Federal se inicia nos instrumentos Plano Plurianual de Investimentos (PPA) ${ }^{5}$, Lei de Diretrizes Orçamentárias (LDO) ${ }^{6}$ e Lei Orçamentária Anual $(\mathrm{LOA})^{7}$. É após a publicação da LOA que se cria o crédito orçamentário no SIAFI, permitindo então a execução orçamentária, onde as

5 O Plano Plurianual - PPA foi instituído pela Constituição Federal de 1988 (art. 165, I e $\S 1^{\circ}$ ), vindo a substituir os anteriores Orçamentos Plurianuais de Investimentos. A competência para remetê-lo ao Congresso Nacional é privativa do Presidente da República, pois, de acordo com o art. 84, Inciso XXIII, da CF, compete privativamente ao Presidente da República enviar ao Congresso Nacional o Plano Plurianual, o projeto de Lei de Diretrizes Orçamentárias e as propostas de orçamento previstas na Constituição. No seio do Parlamento, a proposta de Plano Plurianual poderá receber emendas, apresentadas na Comissão Mista de Planos, Orçamentos Públicos e Fiscalização, onde receberão parecer, que após votado na Comissão, será apreciado pelo Congresso Nacional na forma do Regimento Comum. O projeto de PPA, para vigência até o final do primeiro exercício financeiro do mandato presidencial subseqüente, será encaminhado até quatro meses antes do término do primeiro exercício financeiro

6 Lei de diretrizes Orçamentárias (LDO) - Compreende o conjunto de metas e prioridades da Administração Pública Federal, incluindo as despesas de capital, para o exercício financeiro subseqüente, orientando a elaboração da Lei Orçamentária Anual, dispondo sobre as alterações na legislação tributária e estabelecendo a política de aplicação das agências financeiras oficiais de fomento. (art. 165, § 2, da Constituição Federal, de 5 de outubro de 1988).

7 Lei de diretrizes Orçamentárias (LDO) - Compreende o conjunto de metas e prioridades da Administração Pública Federal, incluindo as despesas de capital, para o exercício financeiro subseqüente, orientando a elaboração da Lei Orçamentária Anual, dispondo sobre as alterações na legislação tributária e estabelecendo a política de aplicação das agências financeiras oficiais de fomento. (art. 165, § 2, da Constituição Federal, de 5 de outubro de 1988). 
despesas públicas previstas e autorizadas pelo Congresso Nacional serão realizadas e por fim, avaliadas pelos órgãos de controle. A Figura 06 demonstra este ciclo.

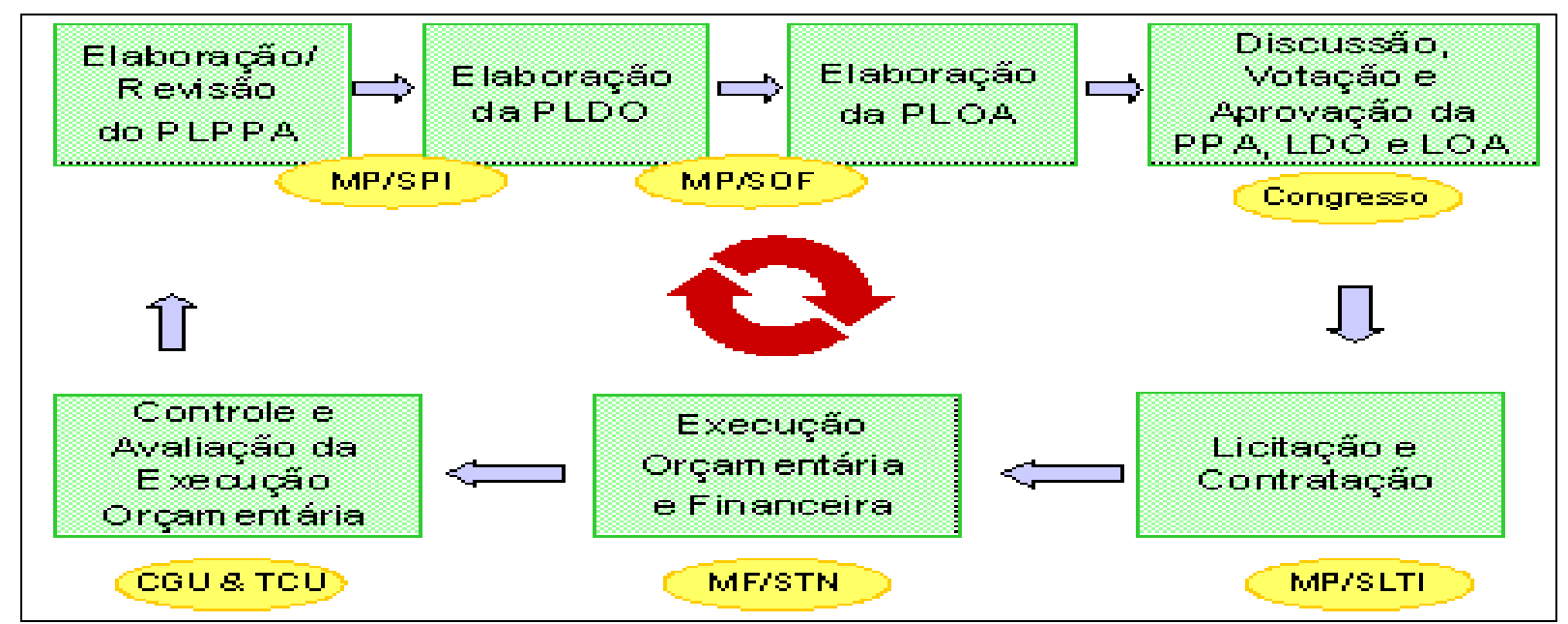

Figura 06 - Ciclo de Gestão e Competências

Fonte: FEIJÓ (2008)

Conforme demonstrado na Figura 06, o processo orçamentário pode ser definido como um processo contínuo e simultâneo que compreende as etapas de Elaboração, Aprovação, Execução e Controle e Avaliação.

A etapa de elaboração é de responsabilidade essencialmente do Poder Executivo, e deve ser compatível com os planos e diretrizes já submetidos ao Legislativo. Os Três Poderes e o Ministério Público têm autonomia para a elaboração de suas propostas, dentro das condições e limites já estabelecidos nos planos e diretrizes. O Órgão Central do Sistema de Orçamento (MOG/SOF) fixa parâmetros a serem adotados por cada Órgão ou Unidade Orçamentária ${ }^{8}$. São dois os níveis de compatibilização:

- Entre as unidades de cada Órgão;

- Entre os vários órgãos da Administração Pública no âmbito do Órgão Central do Sistema de Orçamento.

A etapa de aprovação ocorre por meio da submissão da matéria ao

${ }^{8}$ Segmento da administração direta ou administração indireta a que o orçamento da União consigna dotações específicas para a realização de seus programas de trabalho e sobre os quais exerce o poder de disposição. É o menor nível da classificação institucional, agrupada em órgãos orçamentários, entendidos estes como os de maior nível da classificação institucional' 
Congresso Nacional.

A etapa de execução, sob responsabilidade da STN, é instrumentalizada pelo SIAFI e corresponde ao exercício financeiro, descrito posteriormente.

Por fim, o Controle e Avaliação, conforme a Lei ㄲo 4.320/64 estabelece que o controle seja exercido pelos Poderes Legislativo e Executivo, mediante controles externo e interno, respectivamente.

Esse entendimento é reafirmado pelo Art. 70 da Constituição, que determina que a fiscalização contábil, financeira, orçamentária, operacional e patrimonial da União e das entidades da administração direta e indireta, quanto à legalidade, legitimidade, economicidade, aplicação das subvenções e renúncia de receitas, será exercida pelo Congresso Nacional, mediante controle externo, e pelo sistema de controle interno de cada Poder.

Considerando o ciclo de gestão e competências, estão inseridas neste processo as etapas de:

- Licitação e Contrato

- Execução Orçamentária e Financeira

- Controle e Avaliação da Execução

Logo após a sanção presidencial à Lei Orçamentária aprovada pelo Congresso Nacional, o Poder Executivo mediante decreto estabelece em até trinta dias a programação financeira e o cronograma de desembolso mensal por órgãos, observadas as metas de resultados fiscais dispostas na Lei de Diretrizes Orçamentárias.

A Programação Financeira se realiza em três níveis distintos, sendo a Secretaria do Tesouro Nacional o órgão central, contando ainda com a participação das Subsecretárias de Planejamento, Orçamento e Administração (ou equivalentes os órgãos setoriais - OSPF) e as Unidades Gestoras Executoras (UGE).

Compete ao Tesouro Nacional estabelecer as diretrizes para a elaboração e formulação da programação financeira mensal e anual, bem como a adoção dos procedimentos necessários a sua execução. Aos órgãos setoriais competem a consolidação das propostas de programação financeira dos órgãos vinculados (UGE) e a descentralização dos recursos financeiros recebidos do órgão central. Às Unidades Gestoras Executoras cabem a realização da despesa pública nas suas três etapas, ou seja: o empenho, a liquidação e o pagamento.

O Art. 34 da Lei 4.320 (BRASIL,1964) determina que o exercício financeiro 
esteja contido no ano civil. A Figura 07 exemplifica este ciclo no tempo.

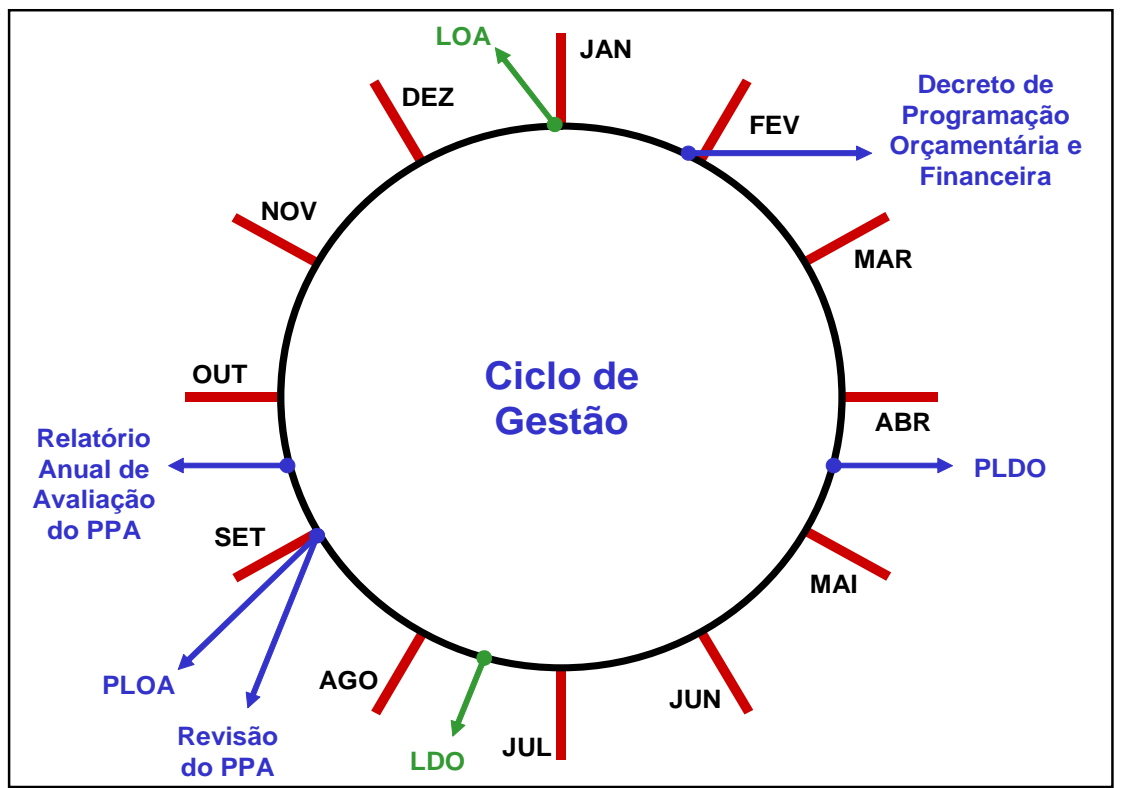

Figura 07 - 0 "Relógio" do Ciclo de Gestão

Fonte: FEIJÓ (2008),

O ciclo orçamentário corresponde ao período de tempo em que se processam as atividades típicas do orçamento público, desde sua concepção até a apreciação final e envolve um período muito maior que o exercício financeiro, uma vez que abrange todas as fases do processo orçamentário, descrito anteriormente.

O ciclo orçamentário não se confunde com o exercício financeiro, este bem mais restrito. Compreende o espaço de tempo entre primeiro de janeiro e trinta e um de dezembro de cada ano, no qual se promove a execução orçamentária e financeira.

O art. 34 da Lei o 4.320/64 determina que o exercício financeiro coincida com o ano civil. $\mathrm{O}$ art. 35 desse mesmo dispositivo legal dispõe que "...pertencem ao exercício financeiro as receitas nele arrecadadas e as despesas nele legalmente emprenhadas." É o Regimento Misto da Contabilidade Pública, de Caixa para as Receitas e de Competência para as Despesas.

Com a publicação da Lei Orçamentária Anual (LOA) e liberação dos dados orçamentários no SIAFI é então realizada a descentralização de créditos para as unidades poderem utilizar os créditos orçamentários que thes tenham sido consignados no orçamento ou thes venham a ser transferidos posteriormente. A 
descentralização pode ser interna, se realizada entre unidades gestoras do mesmo órgão; ou externa, se efetuada entre órgãos distintos.

De acordo com Giacomoni:

[...] dotações consignadas aos créditos orçamentários e adicionais representam autorizações de despesas válidas para utilização no período de vigência da LOA. Para que as despesas possam ser efetivamente realizadas, é necessário que os recursos financeiros estejam disponíveis no momento devido para quitar a obrigação. Como não ocorre automaticamente 0 ajuste entre a entrada efetiva das receitas e as necessidades de pagamento das despesas, o administrador deve precaverse, programando a realização dos gastos de forma harmonizada com o comportamento do fluxo de entrada dos recursos. (GIACOMONI,2007,p.265)

A movimentação de recursos financeiros oriundos do orçamento da União, entre as unidades gestoras que compõem o Sistema de Programação Financeira, se dá sob a forma de liberação de cotas, repasses, sub-repasses para o pagamento de despesas e por meio de concessão de limite de saque à Conta Única do Tesouro.

A Figura 08 resume as descentralizações de créditos e as movimentações de recursos.

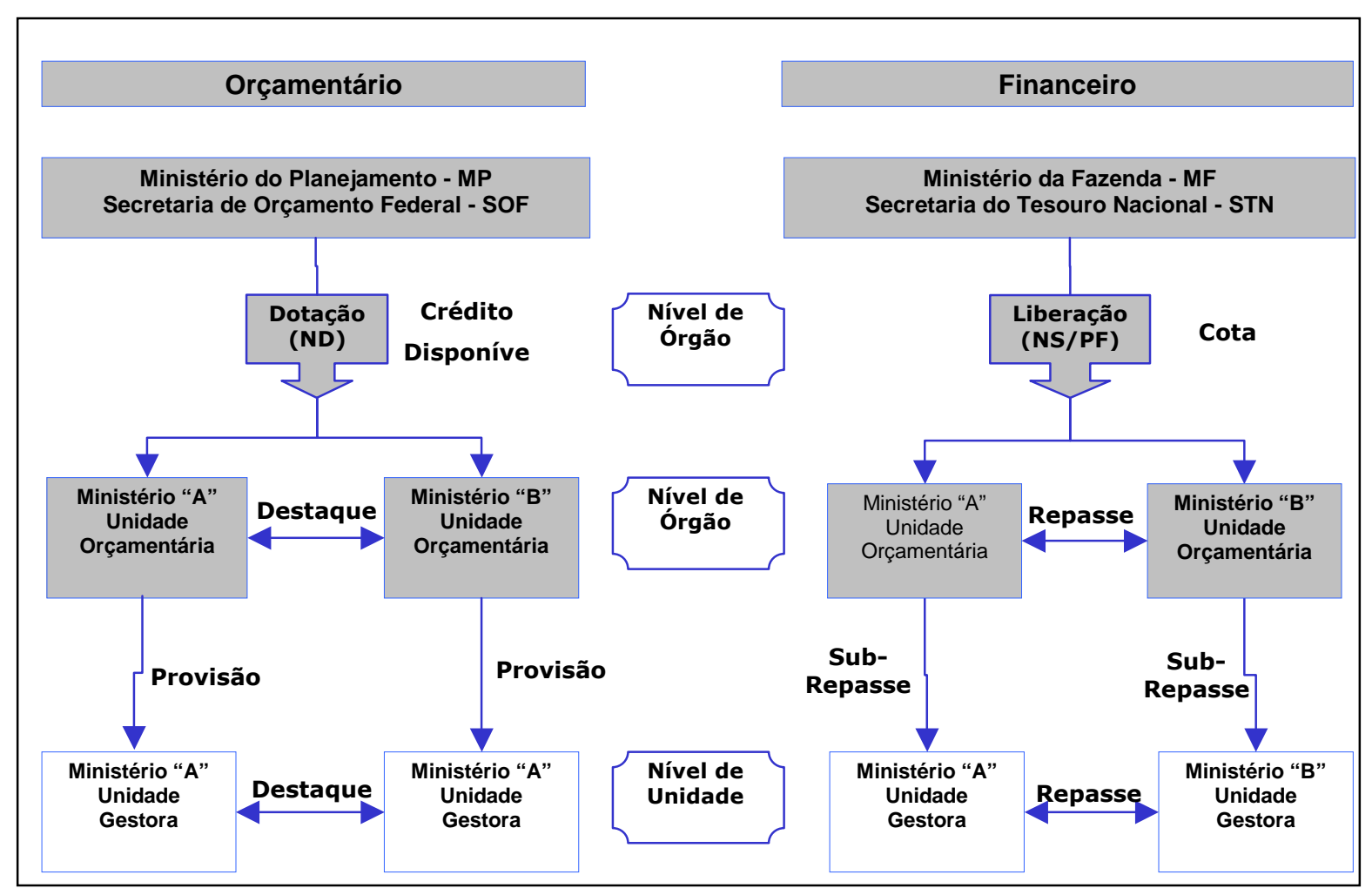

Figura 08 - Descentralização de Créditos x Movimentação de Recursos

Fonte: FEIJÓ (2008) 
A primeira fase da movimentação dos recursos é a liberação de cota que é o montante de recursos colocados à disposição dos Órgãos Setoriais de Programação Financeira (OSPF). A segunda fase é a liberação de repasse, que é a movimentação de recursos realizada pelos OSPF para as unidades de outros órgãos ou ministérios e entidades da Administração Indireta, bem como entre esses.

O sub-repasse é a liberação de recursos dos OSPF para as unidades sob sua jurisdição e entre as unidades de um mesmo órgão, ministério ou entidade.

Após o procedimento de movimentação de créditos, as unidades apresentam disponibilidades financeiras, o que permite o pagamento de suas despesas.

Conforme definido nas normas de execução da despesa pública, a ordem normal no processo de execução orçamentária e financeira é o registro da despesa por meio do documento Nota de Empenho, a liquidação dessa despesa, por meio da Nota de Liquidação, e por fim, o pagamento da despesa por meio de uma Ordem Bancária.

O Empenho é o primeiro estágio da despesa e pode ser conceituado como sendo $o$ ato emanado de autoridade competente que cria para o Estado a obrigação de pagamento pendente ou não de implemento de condição. No SIAFI, este estágio é realizado por meio do documento Nota de Empenho (NE), através de transação específica denominada NE, que se destina a registrar o comprometimento de despesa orçamentária, obedecidos os limites estritamente legais.

A Liquidação é o segundo estágio da execução da despesa, que consiste na verificação do direito adquirido pelo credor, tendo por base os títulos e documentos comprobatórios do respectivo crédito, ou seja, é a comprovação de que o credor cumpriu todas as obrigações constantes do empenho. Esse estágio tem por finalidade reconhecer ou apurar a origem e o objeto do que se deve pagar, a importância exata a pagar e a quem se deve pagar para extinguir a obrigação, sendo efetuado no SIAFI pelo documento Nota de Lançamento (NL).

O Pagamento, último estágio da despesa, consiste na entrega de numerário ao credor do Estado, extinguindo dessa forma o débito ou obrigação. Estabelece a legislação que a despesa somente poderá ser paga após sua regular liquidação. $O$ pagamento é realizado pelo documento Ordem Bancária (OB) ou pelo documento Guia de Recolhimento da União (GRU). Para possibilitar o crédito aos beneficiários 
e as diversas formas de pagamento das despesas da administração pública existem várias modalidades de Ordem Bancária no SIAFI. A Tabela 03 demonstra os tipos de Ordens Bancárias existentes, seu objetivo e a partir de onde ocorre a sua movimentação.

\begin{tabular}{|c|c|c|}
\hline $\begin{array}{l}\text { Tipo de } \\
\text { Ordem } \\
\text { Bancária }\end{array}$ & Objetivo & Movimentação \\
\hline OBC & $\begin{array}{l}\text { Utilizada para pagamentos por meio de crédito em conta corrente do } \\
\text { favorecido na rede bancária e para saque de recursos em conta } \\
\text { bancária para crédito na Conta Única da Unidade Gestora. }\end{array}$ & \multirow{8}{*}{ 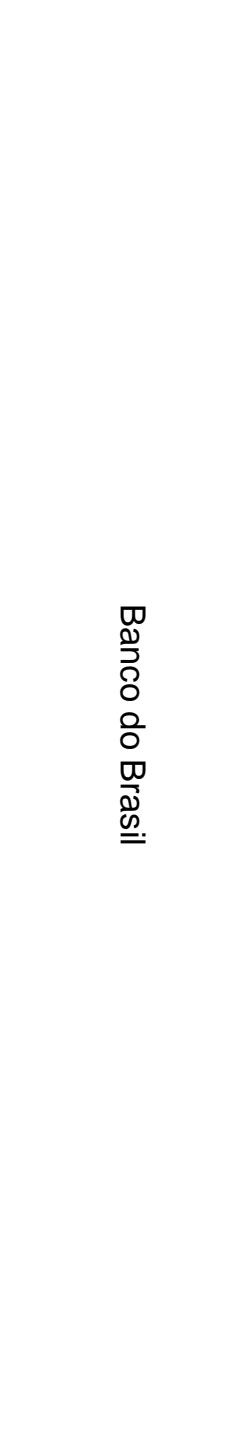 } \\
\hline OBP & $\begin{array}{l}\text { Utilizada para pagamentos diretamente ao credor, em espécie, junto } \\
\text { à agência de domicílio bancário da Unidade Gestora, quaando for } \\
\text { comprovada a inexistência de domicílio bancário do credor ou quando } \\
\text { for necessário tornar disponível de forma imediata os recursos } \\
\text { correspondentes. } \\
\text { Só pode ser utilizada para pagamentos a pessoa física. } \\
\text { No caso de contratação de câmbio à outras instituições que não o } \\
\text { Banco do Brasil, também pode ser utilizada, mas o crédito se dará } \\
\text { somente após dois dias. }\end{array}$ & \\
\hline OBB & $\begin{array}{l}\text { Utilizada para pagamentos a diversos credores, por meio de lista } \\
\text { eletrônica; para pagamentos em que o Agente Financeiro deverá dar } \\
\text { quitação e que não possa ser pago por Ordem Bancária de Fatura; } \\
\text { ou para pagamento da folha de pessoal com lista de credores. }\end{array}$ & \\
\hline OBS & $\begin{array}{l}\text { Utilizada para cancelamento de Ordem Bancária pelo Agente } \\
\text { Financeiro com devolução de recursos correspondentes, bem como } \\
\text { pela Secretaria do Tesouro Nacional para regularização das } \\
\text { remessas não efetivadas. }\end{array}$ & \\
\hline OBA - BB & $\begin{array}{l}\text { Utilizada pelos Órgãos autorizados para aplicações financeiras de } \\
\text { recursos disponíveis na Conta Única ou Institucional. }\end{array}$ & \\
\hline OBK & $\begin{array}{l}\text { Utilizada para operações de contratação de câmbio e pagamento de } \\
\text { diárias em moeda estrangeira, tendo como destinatário o Banco do } \\
\text { Brasil. Exige fechamento prévio de câmbio. Apresenta sempre como } \\
\text { favorecido beneficiário efetivo da contratação do câmbio e é liquidada } \\
\text { para pagamento no mesmo dia. }\end{array}$ & \\
\hline OBSTN & $\begin{array}{l}\text { Utilizada pelas Unidades Gestoras da STN ou por outras por ela } \\
\text { autorizada, para pagamentos específicos de responsabilidade do } \\
\text { Tesouro Nacional, no mesmo dia de sua emissão. } \\
\text { Tem como destinatário o Banco do Brasil. }\end{array}$ & \\
\hline OBD & Utilizada para efetuar pagamentos de faturas com código de barras. & \\
\hline OBJ & $\begin{array}{l}\text { Utilizada para pagamento na mesma data de sua emissão, } \\
\text { decorrente de determinações judiciais específicas não transitadas em } \\
\text { julgado. }\end{array}$ & 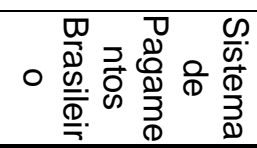 \\
\hline
\end{tabular}




\begin{tabular}{|c|c|c|}
\hline $\begin{array}{l}\text { Tipo de } \\
\text { Ordem } \\
\text { Bancária }\end{array}$ & Objetivo & Movimentação \\
\hline OBR & $\begin{array}{l}\text { Utilizada pelas Unidades Gestoras autorizadas pela Secretaria do } \\
\text { Tesouro Nacional, para pagamentos por meio de cartão de crédito às } \\
\text { contas de Reserva Bancárias dos bancos, bem como de outras } \\
\text { contas mantidas no Banco Central. } \\
\text { O crédito ao beneficiário acontecerá no dia seguinte ao da emissão, } \\
\text { tendo o Tesouro Nacional a prerrogativa de determinar o saque na } \\
\text { Conta Única no mesmo dia da emissão. }\end{array}$ & \\
\hline $\mathrm{OBH}$ & $\begin{array}{l}\text { Utilizada para pagamento parcial ou integral de precatório judicial, } \\
\text { requisição de pequeno valor e outras sentenças judiciais transitadas } \\
\text { em julgado, com crédito no dia seguinte a data de emissão. }\end{array}$ & \\
\hline OBF & $\begin{array}{l}\text { Utilizada para pagamento de despesa relacionada com pessoal, } \\
\text { apropriada por meio de folha de pagamento, com crédito ao } \\
\text { beneficiário no dia seguinte à emissão. } \\
\text { Para crédito no mesmo dia, somente autorizado pela Secretaria do } \\
\text { Tesouro Nacional. }\end{array}$ & \\
\hline OBSPB & $\begin{array}{l}\text { Utilizada para pagamento de despesas diretamente na conta corrente } \\
\text { do beneficiário, em finalidade específica autorizada pela Secretaria do } \\
\text { Tesouro Nacional, com crédito ao beneficiário no dia seguinte ao de } \\
\text { sua emissão. }\end{array}$ & \\
\hline $\begin{array}{l}\text { OBA - em } \\
\text { outros } \\
\text { bancos } \\
\text { BB }\end{array}$ & $\begin{array}{l}\text { Utilizada pelos Órgãos autorizados para aplicações financeiras de } \\
\text { recursos disponíveis na Conta Única ou Institucional, com crédito no } \\
\text { dia seguinte à emissão, quando o destinatário for Instituição } \\
\text { Financeira diferente do Banco do Brasil. }\end{array}$ & \\
\hline
\end{tabular}

Tabela 03 - Tipos de Ordens Bancárias x Agente Financeiro

Fonte: Autora (2009)

\subsection{A CONTA ÚNICA DO TESOURO NACIONAL}

A Conta Única do Tesouro Nacional, mantida no Banco Central do Brasil, acolhe todas as disponibilidades financeiras da União, inclusive fundos, de suas autarquias e fundações. Constitui importante instrumento de controle das finanças públicas, uma vez que permite a racionalização da administração dos recursos financeiros, reduzindo a pressão sobre a caixa do Tesouro, além de tornar ágeis os processos de transferência e descentralização financeira e os pagamentos a terceiros.

Registra-se que os órgãos públicos do orçamento fiscal e da seguridade social estão impedidos de movimentar recursos fora da Conta Única, exceto em alguns casos autorizados pela STN, detalhados posteriormente. De acordo com Albuquerque: 
[...] o Tesouro Nacional atua como se fosse um "banco", os órgãos como clientes fidelizados do "banco Tesouro" e o SIAFI é o sistema utilizado para movimentação das disponibilidades de cada órgão (ALBUQUERQUE; MEDEIROS; FEIJÓ,2008, p.496)

No Art. $1^{\circ}$ da MP n. 2.170-34 (BRASIL, 2001) foi estabelecido que os recursos financeiros de todas as fontes de receitas da União e de suas autarquias e fundações públicas, inclusive fundos por elas administrados, serão depositados e movimentados exclusivamente por intermédio dos mecanismos da Conta Única do Tesouro Nacional, exceto nos casos em que características operacionais específicas não permitam a movimentação financeira pelo sistema de caixa único do Tesouro Nacional, os recursos poderão, excepcionalmente, a critério do Ministro de Estado da Fazenda, ser depositados no Banco do Brasil ou na Caixa Econômica Federal.

Já a Instrução Normativa no 04 - STN de 30/08/2004 trata sobre a consolidação das instruções para a movimentação e aplicação dos recursos financeiros da Conta Única do Tesouro Nacional, a abertura e manutenção de contas correntes bancárias e outras normas afetas à administração financeira dos órgãos e entidades da Administração Pública Federal, que nos seus artigos iniciais define que a Conta Única do TN mantida no BACEN, tem por finalidade acolher as disponibilidades financeiras da União a serem movimentadas pelas Unidades Gestoras da Administração Pública Federal, inclusive Fundos, Autarquias, Fundações, e outras entidades integrantes do SIAFI, na modalidade "on-line" e que sua operacionalização será efetuada por intermédio do Banco do Brasil, ou por outros agentes financeiros autorizados pelo Ministério da Fazenda.

Ainda nesta mesma IN, estabelece que "as contas em moeda estrangeira utilizadas por Unidades Gestoras autorizadas a abrigar as disponibilidades financeiras em moeda estrangeira para pagamento de despesas no exterior, nos termos do Decreto n. 94.007, de 9 de janeiro de 1987".

Assim, depois da implantação do caixa único foi necessária a previsão de manutenção de disponibilidades fora dos mecanismos da Conta Única para atender algumas exceções. $\mathrm{O}$ agente financeiro usado para abertura e manutenção dessas contas é o Banco do Brasil. Essas contas foram classificadas em tipos, de acordo com a sua finalidade: 
- Conta do Tipo A (Unidades Gestoras que operam na modalidade "offline") - Para movimentação das disponibilidades financeiras das unidades gestoras que utilizam o SIAFI, na modalidade "off-line";

- Conta do Tipo B (suprimento de fundos) - Destinada a acolher recursos de suprimento de fundos e de adiantamentos, na impossibilidade de uso do Cartão de Pagamentos do Governo Federal (CPGF). O Decreto n. ${ }^{\circ}$ 6.370 (BRASIL, 2008) proibiu a abertura de novas contas e determinou o encerramento das contas existentes até o final do exercício;

- Conta do Tipo C - Para acolher recursos diretamente arrecadados pelas unidades gestoras, foram extintas com a implantação da sistemática de depósito direto na Conta Única;

- Conta do Tipo D - Destinada ao acolhimento de recursos próprios de entidades participantes na modalidade de uso parcial do SIAFI;

- Conta do Tipo E - Destinada a abrigar as disponibilidades financeiras mantidas no exterior pelas unidades gestoras autorizadas.

Atualmente estão extintas as contas do tipo "C". No caso das contas do tipo "B", estas ainda existem para os poderes Legislativo e Judiciário. No caso do Executivo, este tipo de conta foi desativado, passando a sua função para o CPGF.

O termo "Conta Única" muitas vezes leva ao entendimento de que se embaralham as disponibilidades das diversas áreas de governo, o que prejudicaria a transparência e o controle individualizado, mas esse entendimento não é correto. A conjugação da Conta Única no BACEN e os registros contábeis realizados no SIAFI permitem identificar detalhadamente a fonte do recurso e o uso desses.

O objeto desse estudo está focado nas necessidades de pagamento em moeda estrangeira e na eliminação de contas "particulares" mantidas pelas unidades autorizadas para as disponibilidades financeiras mantidas no exterior. A criação de uma Conta Única em Moeda Estrangeira permitirá, senão a extinção, pelo menos a redução das contas do Tipo "E" e um melhor controle das disponibilidades do Governo Federal em moeda estrangeira.

Atualmente o processo de execução financeira, em muitos casos, ocorre com base na movimentação de contas específicas, onde os recursos necessários às despesas em moeda estrangeira são liberados, em moeda nacional e de acordo com a programação financeira do Tesouro, pela Coordenação-Geral de Programação Financeira (COFIN/STN). Cada unidade gestora executora ao realizar 
a despesa formaliza contrato de câmbio, normalmente junto ao Banco do Brasil para pagamento das despesas (diárias, salários,...).

Este financeiro é revertido para a Unidade Gestora, com transferência do recurso para uma conta "particular da unidade". Os pagamentos realizados a partir dessa conta são contabilizados posteriormente no SIAIFI, e essa contabilização não mantém correspondência com os documentos específicos para esse fim. Ou seja, a ordem de registro dos atos e fatos, via de regra, não ocorre como preconizada pela legislação.

\subsection{O PROCESSO EM REAL E EM MOEDA ESTRANGEIRA}

Conforme definido nas normas de execução da despesa publica, a ordem normal é o registro da despesa por meio do documento Nota de Empenho, a liquidação dessa despesa pela Nota de Lançamento, e por fim, o pagamento da despesa com a Ordem Bancária. A Figura 09 apresenta o fluxo de execução definido e o fluxo atual para despesas em moeda estrangeira.

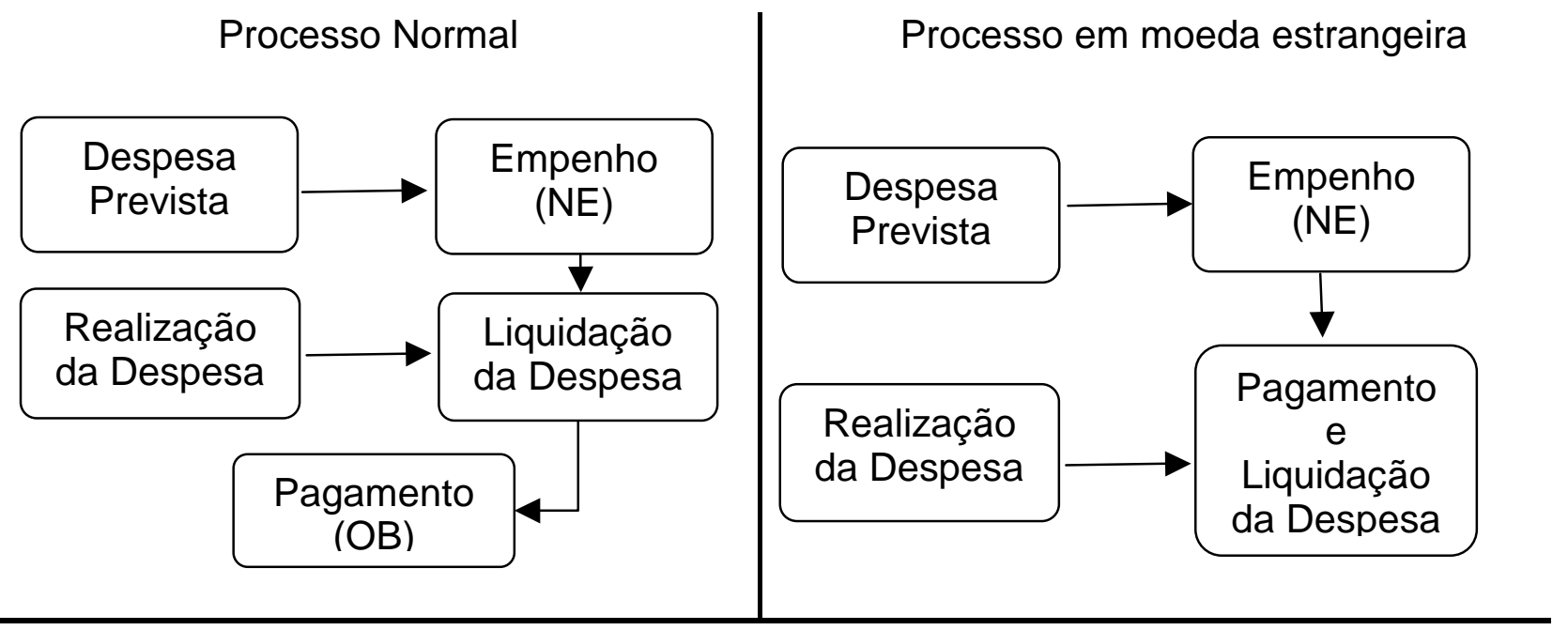

Figura 09 - Fluxo do Registro da Despesa

Fonte: Autora (2009)

Nas unidades localizadas fora do Brasil, o pagamento de despesas ocorre de forma inversa, com o pagamento acontecendo primeiramente. O registro desse 
pagamento no sistema feito por meio do documento NL posteriormente e não pelo documento de pagamento OB.

\subsection{OS INGRESSOS VIA BANCO CENTRAL}

Outro aspecto de abordagem seria o conjunto de ingressos, via Banco Central relacionados com:

- Emissão de títulos/venda de ações no mercado externo

- Empréstimos de organismos internacionais e agências governamentais

Pela regra atual em vigor, as captações externas devem ser direcionadas para pagamento de dívida. Desta forma, em algum momento, os recursos provenientes das emissões externas deverão ser convertidos em reais (momento em que seria feito o contrato de câmbio) e para se evitar o risco de câmbio para o Tesouro Nacional cabe a análise de "operação casada" entre a conversão dos recursos e a saída para pagamento de dívida externa, na possibilidade de uso de filosofia da Conta Única também para as operações envolvendo as Dívidas.

No entanto, em setembro de 2001, a Procuradoria da Fazenda Nacional (PGFN), na análise do aspecto legal sobre o estabelecimento de onde estariam depositados os recursos em moeda estrangeira, por meio do parecer n.. 1321/2001 Coordenação-Geral de Assuntos Financeiros da Procuradoria Geral da Fazenda Nacional (PGFN/CAF), manifestou-se pela manutenção das disponibilidades no Banco Central.

Dessa forma, o escopo desse trabalho foi restringido aos valores em moeda estrangeira, exceto os valores sob gestão do BACEN. 


\section{METODOLOGIA}

Neste tópico, apresentam-se a metodologia e as técnicas de pesquisa a serem adotadas na pesquisa.

O termo metodologia, em sua etimologia, significa o conjunto de métodos e procedimentos técnicos que dirige um processo de pesquisa. É através do método que a pesquisa adquire cientificidade, uma vez que todo conhecimento científico é construído sobre um método. A metodologia, por conseguinte, é um instrumento de procedimento técnico do conhecimento.

Para a pesquisa de campo definiu-se questionário específico onde se pretende coletar dados verbais por meio de entrevista centrada em um problema específico.

A seguir são descritos: o tipo de pesquisa, a amostra a ser pesquisada, o instrumento a ser aplicado, os procedimentos a serem adotados e a forma de análise dos dados coletados.

\subsection{TIPO DE PESQUISA}

A pesquisa pode ser classificada quanto a sua natureza, forma de abordagem, finalidade e meios. Fernandes e Matsumura Gomes (2003) identificam as diversas classificações de pesquisas apresentadas por autores da área de metodologia científica.

Quanto à natureza, o tipo escolhido foi de pesquisa aplicada, com o objetivo de gerar diretrizes para construir um processo aplicável à solução de problemas específicos.

Quanto à forma de abordagem, a pesquisa é caracterizada como qualitativa.

Quanto aos fins, a pesquisa é classificada como exploratória, justificando-se pelo fato de envolver levantamento bibliográfico, entrevistas com pessoas que tem experiências práticas com o problema pesquisado.

A pesquisa exploratória, de acordo com Gil (2007) "tem como objetivo proporcionar maior familiaridade com o problema, com vistas a torná-lo mais explícito ou a construir hipóteses". 
Quanto aos meios, três tipos de procedimentos foram selecionados: pesquisa documental, pesquisa bibliográfica e estudo de caso.

Pesquisa bibliográfica: usada para explorar o assunto e delimitar o trabalho. Pesquisa documental: adotada como uma das técnicas do processo de diagnóstico da forma de aplicação do mecanismo da Conta Única e de seu uso completo no ciclo da despesa, também aplicada à coleta de dados que apóiam o entendimento. Estudo de Caso: usado para validar o processo e encontrar pontos de melhoria.

Este trabalho utiliza a pesquisa bibliográfica, documental e de campo, com análise qualitativa. Quanto aos meios, a pesquisa é bibliográfica, documental e de campo. A pesquisa bibliográfica está centrada na fundamentação teóricometodológica do trabalho, onde foram realizadas pesquisas sobre o assunto em material científico publicado em artigos, livros, revistas, legislação e meios eletrônicos. A investigação foi também documental, porque se valeu de documentos internos da instituição que dizem respeito ao objeto de estudo, como, por exemplo: instruções normativas e manuais. A pesquisa foi de campo, porque coletou dados primários na STN, por meio de aplicação de questionários.

Desta forma, a pesquisa bibliográfica utilizada foi ancorada, principalmente, na observação da literatura existente e no estudo da legislação pertinente aos assuntos disponibilidade, execução orçamentária, execução financeira e Conta Única do TN, e documental ancorada no Manual do SIAFI.

\subsection{POPULAÇÃO E AMOSTRA}

De acordo com Vergara (2000), população é um conjunto de pessoas que possuem os conhecimentos e práticas relacionadas com o assunto objeto da pesquisa e população amostral ou amostra é uma parte do universo escolhida segundo algum critério de representatividade. A população inicialmente identificada neste trabalho fio composta por três coordenações-gerais da STN e por uma unidade de negócio do SERPRO. Ao longo da aplicação do questionário, observouse a necessidade de expandir o universo, face às dificuldades encontradas.

A STN constitui-se o órgão central do Sistema de Administração Financeira Federal e do Sistema de Contabilidade Federal. O Tesouro Nacional tem como missão defender o cidadão-contribuinte, de hoje e de amanhã, por meio da busca 
permanente do equilíbrio dinâmico entre receitas e despesas e da transparência do gasto público. Dentre os principais objetivos estratégicos do TN, destacam-se:

- Promover medidas de políticas econômico-fiscais adequadas e compatíveis com a sustentabilidade macroeconômica do País.

- Aperfeiçoar a Gestão da Dívida Pública Federal de responsabilidade do Tesouro Nacional, desenvolvendo política de gerenciamento de risco e fomentando o mercado secundário de títulos públicos federais, aumentando a base de investidores.

- Aperfeiçoar a programação financeira do Tesouro Nacional, gerenciando a Conta Única, avaliando os gastos governamentais e estabelecendo normas sobre a execução orçamentária, financeira e contábil.

- Buscar o equilíbrio dinâmico e permanente das receitas e despesas públicas.

A STN está organizada em Coordenações-Gerais, conforme abaixo. Cada esfera externa representa uma coordenação. Essas coordenações são agrupadas em secretarias adjuntas, exceto a Coordenação-Geral de Estudos Econômicos e Fiscais, que está ligada diretamente ao Secretário do Tesouro Nacional. A Figura 10 apresenta a organização da STN.

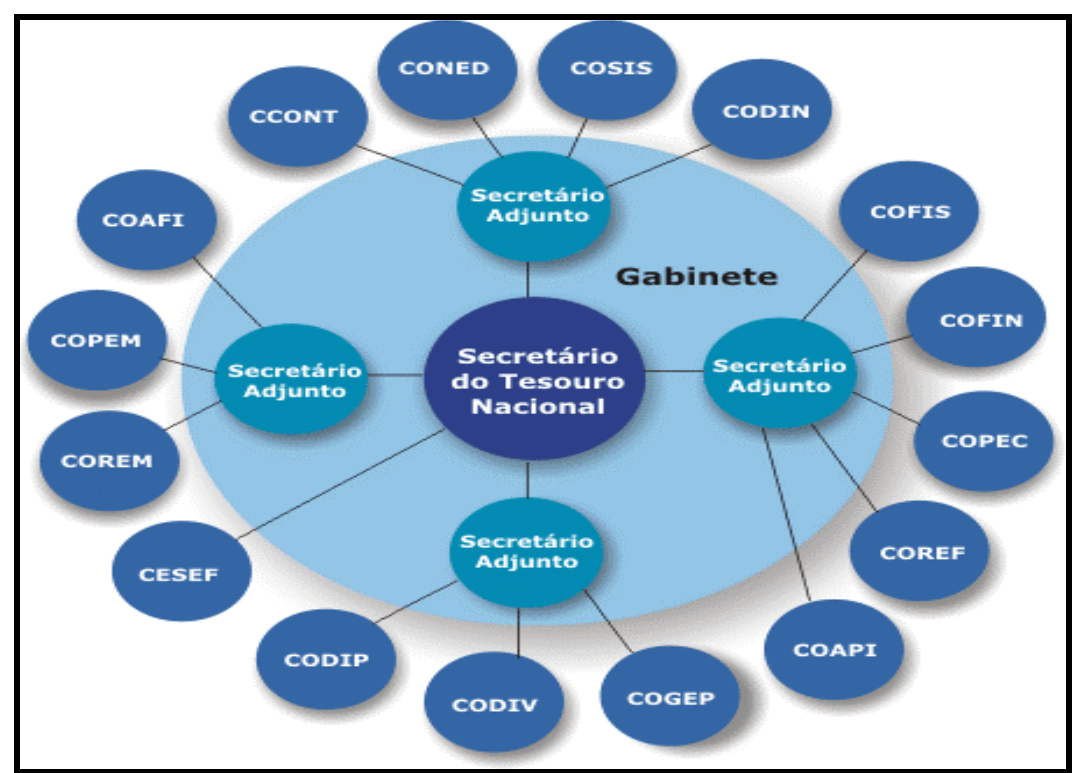

Figura 10: Estrutura Organizacional da STN

Fonte: Sítio do Ministério da Fazenda do Brasil 
O objetivo principal determinante da existência das coordenações na STN está descrito a seguir:

- Coordenação-Geral de Programação Financeira - COFIN - elabora e executa a Programação Financeira e gerencia a Conta Única do Tesouro Nacional.

- Coordenação-Geral de Sistemas e Tecnologia da Informação do Tesouro Nacional - COSIS- gerencia o SIAFI e presta suporte técnico às necessidades e demandas da STN por recursos de tecnologia da informação necessários ao bom desempenho de suas atividades finalísticas.

- Coordenação-Geral de Contabilidade do Tesouro Nacional - CCONT estabelece normas e procedimentos para registro e controle relativos às execuções orçamentária, financeira e patrimonial da Administração Pública, com vistas à produção de informações para tomada de decisão, à elaboração de demonstrações contábeis e à consolidação das contas públicas nacionais.

O SERPRO é uma empresa pública, vinculada ao Ministério da Fazenda. Criada com o objetivo de modernizar e dar agilidade a setores estratégicos da Administração Pública Brasileira, apresenta-se ao mercado com foco na prestação de serviços em Tecnologia da Informação e Comunicações para o setor público.

O mercado de atuação da Empresa é o de finanças públicas, composto pelo Ministério da Fazenda com suas secretarias e demais órgãos, correspondendo a 85,2\% do volume de negócios da Empresa. Outro segmento igualmente importante é o conjunto de ações estruturadoras e integradoras da Administração Pública Federal cuja gestão e articulação competem ao Ministério do Planejamento, Orçamento e Gestão.

O SERPRO está estruturado em diretorias específicas. A Figura 11 mostra a estruturação da organização. No SERPRO, as entrevistas e pesquisa ocorrerão na Superintendência de Negócios Administração Financeira (SUNAF) da Diretoria de Desenvolvimento e Negócios. 


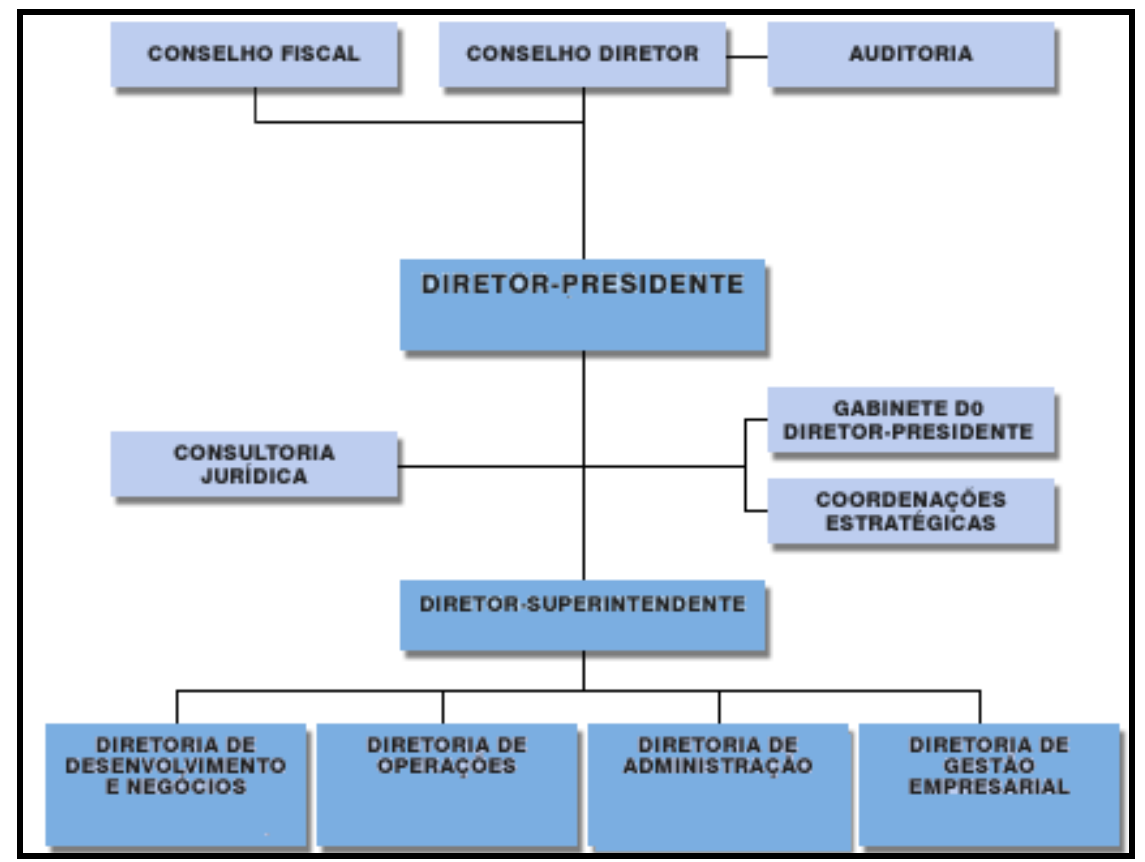

Figura 11: Estrutura Organizacional do SERPRO

Fonte: Sítio do SERPRO

O público alvo das entrevistas na STN é o conjunto de servidores ocupantes do cargo de Analista de Finanças e Controle do quadro da STN, com mais de dois anos de exercício da função, lotados nas coordenações relacionadas. Essas pessoas foram escolhidas pelo alto grau de conhecimento sobre o assunto, por serem gestoras e idealizadoras de normas e procedimentos aplicados à gestão de disponibilidades. O perfil de conhecimento dessas pessoas está ancorado nos seguintes temas:

- Gestão orçamentária, financeira e patrimonial, análise contábil, auditoria contábil e de programas;

- Análise, pesquisa e perícia dos atos e fatos de administração orçamentária, financeira e patrimonial;

- Legislação econômico-fiscal e financeira;

- Programação financeira anual e plurianual da União.

No SERPRO, o público alvo das entrevistas é constituído pelo grupo de gerentes das coordenações de negócio, responsáveis pelo atendimento ao TN, formado por pessoas com mais de 10 anos de experiência na área de TI\&C e reconhecidas pela STN em função do alto grau de conhecimento no segmento objeto de estudo.

Observando-se a literatura, a pesquisa pela qual se opta neste trabalho 
considera a acessibilidade porque seleciona os elementos pela facilidade de acesso a eles e a tipicidade porque é constituída pela seleção de elementos que o pesquisador considera de extrema representatividade, o que requer profundo conhecimento dessa população. Quanto às entrevistas, estas ocorreram apenas no Serviço Federal de Processamento de Dados (SERPRO). Em relação aos demais relacionados, apenas a análise do questionário respondido.

\subsection{AMOSTRAGEM REPRESENTATIVA}

A amostra desta pesquisa apresentou a seguinte representatividade:

- Um representante da Coordenação de Sistemas (COSIS);

- Dois representantes da Coordenação-Geral de contabilidade (CCONT);

- Dois representantes da Coordenação-Geral de Dívida (CODIV);

- Quatro representantes da Coordenação de Programação Financeira (COFIN);

- Dois representantes das Coordenações de Negócio da SUNAF/SERPRO;

- Um representante do Ministério do Planejamento;

- Dois representantes da Câmara dos Deputados Federais.

\subsection{INSTRUMENTO}

O instrumento de pesquisa utilizado foi construído pela entrevistadora foi refinado a partir de sua aplicação, como um teste prévio, no âmbito do SERPRO. Após esta validação do instrumento, o mesmo fio enviado aos entrevistados, que retornaram com suas respostas. As pessoas selecionadas estão entre os que possuem maior conhecimento da estratégia, da missão, dos valores, dos processos e da cultura da organização, visando à coleta de dados para construção do entendimento e proposta para solução do problema-alvo desse estudo. 
padronizados, a pesquisa qualitativa considera cada problema objeto de uma pesquisa específica para a qual são necessários instrumentos e procedimentos específicos. (GUNTHER, 2006 p.204)

O instrumento construído para a coleta dos dados, na forma de um questionário é um formulário com perguntas abertas, e foi elaborado de maneira a investigar as percepções, expectativas e sugestões dos gerentes quanto às competências necessárias para atualização das normas atuais e do SIAFI, para aperfeiçoamento do processo atual.

$\mathrm{Na}$ pesquisa documental foram observados os segmentos Conta Única na Moeda Real, Conciliação Bancária, Aplicação Financeira e Visão de Caixa. Foram observados documentos sobre movimentação de moeda estrangeira, componentes do mercado financeiro, regulamentação bancária e operação no Exterior e Manual SIAFI.

\subsection{PROCEDIMENTOS DA COLETA DE DADOS}

De acordo com o Gil (2007), "a pesquisa documental assemelha-se muito à pesquisa bibliográfica”, pois ambas se valem de material bibliográfico.

Desta forma, a coleta de dados se deu com a leitura de documentos referentes aos procedimentos de Execução Orçamentária e Financeira, Conta Única do TN e informações sobre o sistema bancário disponíveis no BACEN, bem como da legislação aplicada ou de alguma forma envolvida com o tema.

Quanto à aplicação do questionário, optou-se pelo envio por e-mail, seguido de contato telefônico para esclarecimentos acerca do trabalho em desenvolvimento.

Especificamente em relação ao questionário, pelo retorno de respostas obtidas pode-se comprovar que o assunto é pouco disseminado, apresentando-se um excelente objeto de estudo.

Foram enviados 15 questionários para pessoas com reconhecido conhecimento e de destaque na administração federal, no entanto o assunto é de alta complexidade e vários entrevistados não se sentiram à vontade para responder as questões apresentadas.

A Tabela 04 apresenta o percentual de respondentes apurado durante 0 levantamento. 


\begin{tabular}{|c|c|c|c|c|}
\hline $\begin{array}{c}\text { Unidade } \\
\text { Entrevistada }\end{array}$ & Respondente & $\begin{array}{c}\text { Não } \\
\text { respondente }\end{array}$ & Total & Participação \\
\hline SERPRO & 2 & 0 & 2 & $100,00 \%$ \\
\hline STN & 4 & 6 & 10 & $40,00 \%$ \\
\hline Câmara & 0 & 2 & 2 & $0,00 \%$ \\
\hline MP & 1 & 0 & 1 & $100,00 \%$ \\
\hline Total & 7 & 8 & 15 & $46,67 \%$ \\
\hline
\end{tabular}

Tabela 04 - Situação de resposta ao questionário aplicado

Fonte: Autora (2009)

\subsection{ANÁLISE DOS DADOS}

Com relação ao conjunto de dados analisados, as modificações relacionadas com o SIAFI se apresentam nos seguintes processos, conforme Tabela 05:

\begin{tabular}{|c|c|}
\hline $\begin{array}{l}\text { Tipo } \\
\text { Transações }\end{array}$ & Identificação \\
\hline & Balancete contábil - Balancete \\
\hline & Lista de credores - CONLC e ATULC \\
\hline & Valor limite da Ordem Bancária - CONLIMOB e ATULIMOB \\
\hline & Ordem Bancária - CONOB, CANOB, IMPOB e OB \\
\hline & Consulta relações Pendentes - CONRELPEN \\
\hline & $\begin{array}{l}\text { Relaciona Ordens } \\
\text { RELOBPNIMP }\end{array}$ \\
\hline & Cancela Relação de Ordem Bancária Externa - CANREL \\
\hline & Nota de Lançamento de Variação Cambial - NL \\
\hline & Imprime relação de Ordem Bancária - IMPRELOB \\
\hline & Consulta movimento Bancário - CONMOVBANC \\
\hline & Registra Conciliação da Conta Institucional - REGCONCCTM \\
\hline & $\begin{array}{l}\text { Registra Conciliação da Conta Única do Tesouro Nacional - } \\
\text { REGCONCCTU }\end{array}$ \\
\hline & Consulta pendência na Conta Única - CONPENDCTU \\
\hline & Códigos da Conta Única - CONCODCUT e ATUCODCTU \\
\hline & $\begin{array}{l}\text { Registro de valor limite de Ordem Bancária de Pagamento para } \\
\text { Conta Única - REGLIMOBP }\end{array}$ \\
\hline & Disponibilidades - CONCAIXA, ATUINCAIXA e ATUPARCX \\
\hline & Liberação de Ordem Bancária de Reserva - ATUREMOB \\
\hline & Taxa de Conversão - CONTAXCONV \\
\hline & Taxa de Câmbio - CONCAMBIO e ATUCAMBIO \\
\hline & Registra Nota de movimentação de Crédito - NC \\
\hline
\end{tabular}




\begin{tabular}{|c|c|}
\hline Tipo & Identificação \\
\hline & Registra Darf Eletrônico - DARF \\
\hline & $\begin{array}{l}\text { Atualização de Taxa - ATUTIPTAXA, INCTIPTAXA, CONTIPTAXA, } \\
\text { REATIPTAXA, EXCTIPTAXA }\end{array}$ \\
\hline Procedimentos & Registro dos efeitos de ajustes da variação cambial \\
\hline & Encerramento de Exercício \\
\hline & Regulamentação de Unidade Gestora no Exterior \\
\hline & Elaboração e Execução Orçamentária \\
\hline & Programação e Execução Financeira \\
\hline & Conta Única do Tesouro Nacional \\
\hline & Restos a Pagar \\
\hline Outros & Processo batch da Conta Única \\
\hline Processos & Processo batch para conciliação bancária \\
\hline & Processo de tratamento de mensagens SPB \\
\hline & Processo de transferência de dados para o SIAFI Gerencial \\
\hline & hath of \\
\hline
\end{tabular}

Tabela 05 - Tipos de Ordens Bancárias x Agente Financeiro

Fonte: Autora (2009) 


\section{RESULTADOS}

Relembrando, o estudo ora apresentado tem como objetivo tratar a adoção da sistemática de Conta Única para os recursos em moeda estrangeira, confrontando-se à legislação que suporta a Conta Única e sua aderência para acomodar mecanismos que permitam a implantação de outras moedas, verificando a aderência do SIAFI na implantação do mecanismo, relacionando-se as possibilidades de modificações no SIAFI (e outros sistemas) para propiciar uma visão integrada das disponibilidades de recursos e o registro dos Atos e Fatos no momento de sua ocorrência.

Outro aspecto observado é a identificação de outros recursos que não estão inseridos na filosofia da Conta Única.

Considerando a legislação pertinente e as respostas obtidas dos especialistas entrevistados, é possível e viável implementar o mecanismo para tratamento das operações em outras moedas. 


\section{DISCUSSÃO DOS RESULTADOS}

O ingresso de recursos em moeda estrangeira para o caso de emissões de títulos no mercado financeiro internacional, o valor em moeda estrangeira é ingressado no País por meio do Banco Central (reservas internacionais) e o contra valor em reais é transferido para a Conta Única do Tesouro Nacional, registrado como receita de emissão de títulos públicos. Estes recursos são "carimbados" e devem ser utilizados na amortização da dívida pública federal.

Quanto ao o Processo de empréstimos de organismos internacionais e agências governamentais o desembolso ao governo brasileiro é efetuado mediante crédito a um agente financeiro no Brasil, usualmente o Banco do Brasil (BB), indicado na forma prevista no contrato de empréstimo. O BB providencia um contrato de câmbio, adquirindo a moeda estrangeira e creditando o valor correspondente na moeda nacional, o Real, à Conta Única do Tesouro Nacional.

Os recursos recebidos em moeda estrangeira são convertidos em real antes de ingressarem na Conta Única, conforme explicado anteriormente e via SPB/BACEN e não há outra forma de ingresso na CTU.

O Decreto n. 4.992 (BRASIL, 2004) alterou a sistemática de execução financeira de projetos financiados com operações de crédito externas, buscando principalmente a transparência do processo e aprimorar os mecanismos de controle e responsabilização. Conforme o decreto, os riscos cambiais

Até recentemente havia um trâmite dos valores desembolsados a crédito de uma conta especial, do Tesouro Nacional, junto ao BB. Os valores permaneciam nesta conta até que a STN autorizava sua liberação para o órgão executor. O objetivo foi evitar que os valores desembolsados ficassem esterilizados na Conta Única e perdessem o poder de compra em decorrência do processo inflacionário, enquanto transcorriam os procedimentos de execução da despesa, mencionados anteriormente: licitação, elaboração e entrega de produtos e obras, liquidação, pagamento. Os recursos depositados na conta especial eram remunerados para 0 Tesouro Nacional.

As contas especiais estão diretamente relacionadas aos acordos de empréstimos ou contribuições Financeiras não reembolsáveis e são exclusivamente movimentadas pela COFIN/MF. Estas contas.

O processo de transferência de recursos para a Conta Única do Tesouro, 
ocorre através das Ordens Bancárias emitidas pelas Unidades Gestoras, por pagamento por Guia de Recolhimento da União, ou por recolhimento de receitas que são creditadas diretamente na Conta Única, considerando todas as arrecadações federais e previdenciárias, venda de títulos do TN, tanto feita pelo cidadão comum na rede bancária como as diretamente arrecadadas pelas Instituições Financeiras utilizando o Sistema de Pagamentos Brasileiro do Banco Central do Brasil. Também as receitas diretamente arrecadadas pelos Órgãos Federais são recolhidas diretamente à Conta Única, através do documento GRU.

Se a arrecadação ocorre no exterior, ela é captada pelo Banco do Brasil por meio de modalidade Swift ${ }^{9}$, identificando a que se refere aquele pagamento e, então o Banco do Brasil efetua o recolhimento para a Conta Única por meio de Guia de recolhimento da União por se tratar de recurso do Tesouro Nacional, repassados por meio do SPB.

A arrecadação dentro do território nacional é realizada por qualquer banco que possuir reserva no BACEN e que estiver preparado para utilizar as mensagens de troca de informações com o Tesouro, as mensagens do Grupo STN.

Com relação às liberações para pagamento de despesa no exterior, cada Unidade Gestora estabelece um contrato de Cambio, com a Instituição Financeira, sendo celebrado diretamente com a Unidade Gestora do SIAFI. Essa contratação pode se realizar em qualquer banco autorizado a operar em câmbio no Brasil.

No caso dos pagamentos da Dívida Externa os recursos são sacados da Conta Única em reais e utilizados para aquisição de moeda estrangeira, necessária ao pagamento do compromisso devido.

No caso de pagamento de pessoal e de custeio no exterior, o Órgão responsável pela UG do exterior, emite uma Ordem Bancária de Câmbio (OBK) com a taxa de cambio do momento da emissão e na moeda de origem da despesa.

Para o pagamento referente aos projetos financiados por organismos Internacionais ou de terceiros, também ocorre por meio de emissão de OBK do Órgão responsável em favor da Instituição contratada.

Quanto à criação de contas contábeis em moeda estrangeira e respectiva disponibilidade por fonte, não é necessário, pois o SIAFI não necessita de contas específicas em moeda estrangeira. $O$ que será registrado são as movimentações financeiras em moedas estrangeiras. Quanto a fonte de recursos, deve-se criar uma

\footnotetext{
${ }^{9}$ A modalidade Swift é um tipo de transferência de recursos efetuada pelo Sistema Swift.
} 
Fonte de Recursos para identificar esta movimentação em moeda estrangeira.

Os saldos movimentados pelas Unidades Gestoras serão na moeda especificada para unidade operar.

Não há qualquer óbice legal, técnico ou operacional para que a medida seja implantada, no entanto, deve-se observar o disposto na Lei 4.595/64, que de acordo com a Procuradoria Geral da Fazenda Nacional, as disponibilidades em moeda estrangeira da União, se constituem nas reservas internacionais e devem ser obrigatoriamente depositadas no Banco Central do Brasil.

Com relação ao decreto de programação financeira e outros procedimentos necessários a criação da conta de limite de saque em moeda estrangeira, por se tratar de assunto de competência do Secretário do Tesouro Nacional ou do Ministro da Fazenda, uma simples Portaria do Ministério da Fazenda ou da Secretaria do Tesouro Nacional seria suficiente para implantar a Conta Única em Moeda Estrangeira.

Atualmente o SIAFI permite movimentações em outras moedas, a exemplo das moedas Euro e len. Desta forma, o estabelecimento da Conta Única em Moeda Estrangeira pode ocorrer para várias moedas. Há de se avaliar com mais profundidade os impactos e as dificuldades geradas a partir desta afirmação, pois os mecanismos de controle da Conta Única, bem como o processo de conciliação bancária, quanto mais moedas forem contempladas, apresenta dificuldade exponencial de implementação.

Para atender a Conta Única em Moeda Estrangeira seria necessário estabelecer uma Ordem Bancária de Movimentação de Moeda Estrangeira (OBME). Esta OBME poderia movimentar a reserva pelo SPB, já que reserva bancária é um movimento entre contas reservas das Instituições Financeiras que residem no Banco Central e a Instituição Financeira recebedora da movimentação de reserva operar pelo Sistema Swift ${ }^{10}$ para a movimentação ao exterior.

Sendo o catálogo de mensagens um documento elaborado em conjunto com os participantes do SPB e que se considerada como viável pela Secretaria do Tesouro Nacional a proposta ora apresentada, seria necessário submeter ao Banco Central - Grupo de Trabalho Mensagens as modificações necessárias para

${ }^{10}$ O sistema SWIFT é uma rede mundial interbancária financeira que permite a transferência de valores entre bancos dispersos nos cinco continentes. Cada banco tem um código que o identifica e se realiza por meio de mensagens pré-definidas. 
adequação do catálogo de mensagens, de forma a acomodar a finalidade de transferência ao exterior a partir da OBME.

De modo a facilitar o processo e manter as operações em banco do governo brasileiro, seria recomendável privilegiar a adoção do Banco do Brasil como Instituição Financeira conveniada para pagamento no Exterior, pois dispõe de representações nas principais praças onde o governo brasileiro opera.

Hoje o Banco do Brasil é a Instituição Financeira conveniada para isto. No SIAFI não aparece como tal, por que a sistemática existente destas movimentações não é clara e visível como sendo movimentações de recursos oriundos da Conta Única, mas que na realidade o são.

É recomendável também que se estabeleça forma padrão de fechamento de câmbio. Considerando o escopo aplicado para as transações em Moeda Estrangeira, seria relevante definir pelo menos dois padrões: um para movimentos realizados pela STN, como por exemplo, para suprimento da Conta Única em moeda estrangeira, aplicação de disponibilidades e incorporação de saldos não utilizados, mediante conversão para reais e um outro padrão de contrato para viabilizar os registros, no BACEN, das operações em moeda estrangeira executadas pelas Unidades Gestoras autorizadas para tal. 


\section{CONCLUSÕES}

Atualmente não existem recursos à Conta Única em Moeda Estrangeira. No entanto, é possível implantar uma Conta Única do Tesouro Nacional em Moeda Estrangeira. O que dificultou a implantação dessa solução, no passado, foi a ausência de recursos tecnológicos que viabilizassem a operacionalização do SIAFI fora do País. No entanto, as novas facilidades da tecnologia da informação, como por exemplo, os sistemas de mensageria, eliminaram esse entrave.

Alguns benefícios seriam obtidos com a implantação de uma Conta Única em Moeda Estrangeira, como facilidade operacional para os órgãos que realizam recebimentos e pagamentos em moeda estrangeira, visto que os recebimentos e pagamentos poderiam ser realizados diretamente no SIAFI. Para tanto, alguns aspectos deverão ser considerados se a conta for abrigar valores em moedas distintas, tais como:

a) Todos os movimentos da Conta Única em Moeda Estrangeira teriam que observar procedimentos de registro de câmbio estabelecidos pelo Banco Central. Para tanto, o mecanismo automático existente atualmente de troca de informações entre SIAFI e SISBACEN seria suficiente;

b) Um agente financeiro no exterior deveria assumir o mesmo papel que hoje exercem o Banco Central e o Banco do Brasil na movimentação da Conta Única. No caso apresentado, sugere-se que seja o próprio BB.

Caberia a esse agente financeiro acolher, no Brasil ou no exterior, as Ordens Bancárias contra a Conta Única em Moeda Estrangeira, realizar o processo de verificação de assinaturas (física ou digital) e executar as ordens de pagamento a terceiros no exterior. O mesmo ocorreria em caso de recebimento de recursos pagos ou liberados por terceiros diretamente a unidades gestoras integrantes do SIAFI. Para isso, caberia instituir mecanismo de recebimento de receitas/créditos em outras moedas diretamente à Conta Única em Moeda Estrangeira, como o atual mecanismo da Guia de Recolhimento da União.

É recomendável também que a Unidade Gestora possa utilizar disponibilidades em moeda estrangeira para realizar pagamentos em reais, no Brasil. Nesse caso, poderá haver mecanismo de conversão automática no SIAFI, mediante utilização de uma tabela de conversão para taxa de câmbio que vier a ser 
definida, podendo ser diária, baseada em taxa média ou alguma outra.

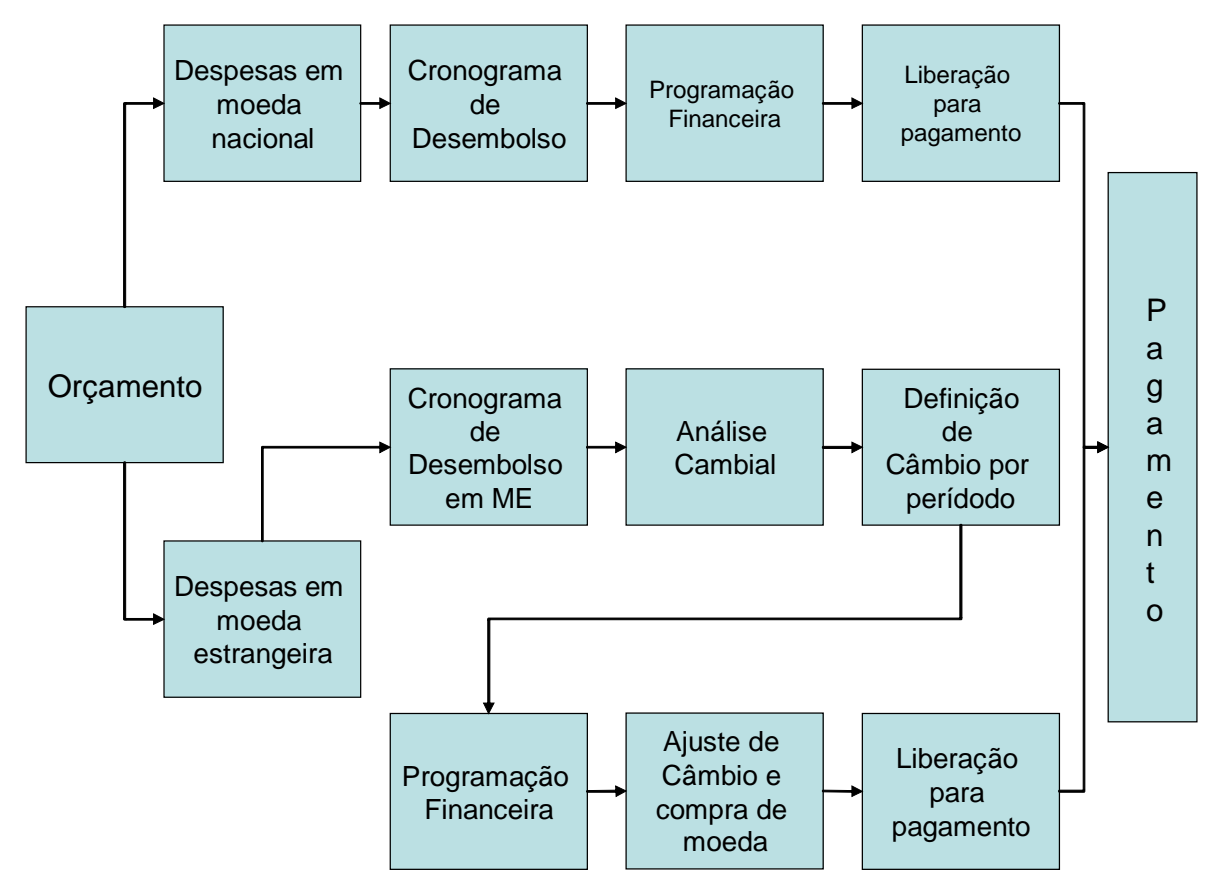

Figura 12: Esquema de Liberação de Financeiro

Fonte: Autora

Não foi objeto deste estudo a função de Programação Financeira, mas para que se implante a Ordem Bancária em Moeda Estrangeira, é necessário se estabelecer como se dará a Programação Financeira. A Figura 12 aborda uma proposta inicial para o fluxo de liberação, considerando a análise das despesas no tempo em relação ao comportamento do câmbio,de forma a identificar as melhores datas para compra de moeda buscando mitigar riscos de flutuação ao TN.

A Secretaria do Tesouro Nacional é o órgão responsável pela administração e utilização dos recursos que entram nos cofres do Governo Federal provenientes, principalmente, dos tributos pagos pelos contribuintes. A atual legislação estabelece como atribuições da STN a elaboração e execução da programação financeira da União; a administração dos haveres financeiros e mobiliários (títulos), bem como das responsabilidades da União; e a execução das operações de crédito e da política de dívida pública federal, interna e externa, bem como o controle dos limites de endividamento do setor público.

Conforme determina 0 art. $5^{\circ}$ do Decreto o 93.874 , de 23/12/86, a 
programação financeira tem por finalidade a formulação de diretrizes para elaboração das propostas de cronogramas de desembolso, estabelecimento do fluxo de caixa e fixação de limites de saques periódicos contra a Conta Única do Tesouro Nacional, objetivando:

a) assegurar às unidades orçamentárias, em tempo oportuno, a soma de recursos necessários e suficientes à melhor execução do seu programa anual de trabalho; e

b) manter, durante o exercício, na medida do possível, o equilíbrio entre a receita arrecadada e a despesa realizada, de modo a reduzir eventuais insuficiências financeiras.

Compete à STN aprovar a programação financeira de desembolso para o exercício, procurando ajustar as necessidades da execução do orçamento/programa ao fluxo de caixa do Tesouro. A programação financeira é um conjunto de ações desenvolvidas e relacionadas ao orçamento de caixa, compreendendo a previsão do comportamento da receita, a consolidação dos cronogramas de desembolso e o estabelecimento do fluxo de caixa. Já o fluxo de caixa do Tesouro é mais abrangente do que o cronograma de desembolso, pois ele engloba não só as despesas, mas também as receitas do Governo.

Por fim, o cronograma de desembolso é o instrumento pelo qual a unidade orçamentária projeta no tempo o pagamento das despesas autorizadas na lei orçamentária relativas a cada item do seu programa de trabalho.

Conforme registrado anteriormente, para a implantação da OBMR há de se considerar a revisão do processo de programação financeira de forma a contemplar as diversas moedas, o comportamento do mercado financeiro e as possíveis oscilações destas moedas, para que o cronograma de desembolso possa comportar as variações e ajustes necessários frente aos compromissos. Este estudo se apresenta como uma nova oportunidade de pesquisa. 


\section{REFERÊNCIAS}

ALBERTIN, Rosa M. Moura; ALBERTIN, Luiz Alberto Benefícios do Uso de Tecnologia da Informação para o Desempenho Empresarial, RAP, Rio de Janeiro, n.42, p275-302, mar./abr. 2008

ALBUQUERQUE, Claudiano M.;MEDEIROS Marcio.;FEIJO, Paulo Henrique Fundamentos e Prática de Planejamento, Orçamento e a Administração Financeira com Responsabilidade Fiscal, 2.ed.rev.e aum. Brasília: Autores, 2008

CASTRO, Domingos Poubel; GARCIA, L. M. Reformulação das Finanças Públicas no Brasil. In: . Contabilidade Pública no Governo Federal. 2.ed.rev.e aum., São Paulo: Atlas, 2008. cap.3.

CLEMENTE, Fabiane Pesquisa qualitativa, exploratória e fenomenológica: Alguns conceitos básicos, publicado em 05/08/2007 em http://www.administradores.com.br/artigos. Acesso em Fev./2009

FERNANDES, Luciane Alves; MATSUMURA GOMES, José M. Relatórios de pesquisa nas ciências sociais: características e modalidades de investigação, Contexto, Ed. 4, Jan-Jun/2003, Disponível em http://www.ufrgs.br/necon. Acesso Fev./2009

FUJI, Alceu Haruo. Contabilização de Títulos e Valores Mobiliários: Uma Comparação entre as Normas Brasileiras do FASB e do IASB, R Cont. Fin. USP, São Paulo, v.19,n.47,p112-123, mai./ago.2008

GIACOMONI, James. Execução Orçamentária e Financeira. In: Orçamento Público, 13.ed. São Paulo: Atlas, 2007. cap.14.

GIL,Antônio Carlos. Como elaborar projetos de pesquisa, 4.ed. São Paulo, Atlas, 2007. 
GODOY, Arilda. S. Introdução à pesquisa quantitativa e suas possibilidades, RAE, São Paulo, v. 35, n.2, p57-63, mar./abr. 1995

GUNTHER, Hartmut. Pesquisa Qualitativa versus Pesquisa Quantitativa: esta é a questão?. Psicologia. Teoria e Pesquisa, v. 22, p. 201-209, 2006.

PINTO, Liane. Ferreira, MOTA, Francisco. Glauber L., FEIJÓ, Paulo Henrique. Curso de SIAFI. Uma abordagem prática da execução orçamentária e financeira, 2.ed.rev.e aum. Brasília: Autores, 2008

RODRIGUES FILHO, José.; GOMES, Natanael Pereira. Tecnologia da Informação no Governo Federal, RAP, Rio de Janeiro,n.38,p93-108,jan./fev.2004

SARNEY, J. A cultura do Poço sem Fundo, Folha de São Paulo, São Paulo, 25/06/1993

VERGARA,S.C. Projetos e Relatórios de Pesquisa em Administração, 3.ed. Atlas, São Paulo, 2000

BRASIL. Constituição Federal de 1988 - Artigo n. .0164 , §3

BRASIL. Coordenação-Geral de Assuntos Financeiros da Procuradoria Geral da Fazenda Nacional - PGFN/CAF Parecer n.o 1321/2001. Disponível em: $<$ http://www.fazenda.tesouro.gov.br>. Acesso em Nov./2008

BRASIL. Decreto-Lei n.o 200, de 25 de fevereiro de 1967. Disponível em: $<$ http://planalto.gov.br>. Acesso em Nov./2008

BRASIL. Decreto no. 4.992, de 18 de fevereiro de 2004. Disponível em: <http://www.senado.gov.br>. Acesso em Nov. e Dez./2008

BRASIL. Decreto n.o 6.370 , de 6 de fevereiro de 2008. Disponível em: $<$ http://planalto.gov.br>. Acesso em nov./2008 
BRASIL. Decreto no. 92.452, de 10 de março de 1986. Disponível em: $<$ http://www.senado.gov.br>. Acesso em nov./2008

BRASIL. Decreto no. 93.214, de 03 de setembro de 1986. Disponível em: $<$ http://www.senado.gov.br>. Acesso em Nov./2008

BRASIL. Decreto no. 93.872, de 23 de dezembro de 1986. Disponível em: $<$ http://planalto.gov.br>. Acesso em Nov./2008

BRASIL. Decreto no. 93.874, de 23 de dezembro de 1986. Disponível em: $<$ http://www.senado.gov.br>. Acesso em Nov./2008

BRASIL. Decreto no. 94.007, de 09 de janeiro de 1986. Disponível em: <http://www.senado.gov.br>. Acesso em Nov. e Dez./2008

BRASIL. Lei n.o 4.320, Arts. 34, 35 e 56. de 17 de março de 1964. Disponível em: $<$ http://planalto.gov.br>. Acesso em Nov./2008

BRASIL. Lei n. 4.595, Art. 10. de 31 de dezembro de 1964. Disponível em: $<$ http://planalto.gov.br>. Acesso em Nov./2008

BRASIL. Medida Provisória n.o 2.170-34, Art. 1. de 28 de junho de 2001. Disponível em: <http://planalto.gov.br>. Acesso em Nov./2008

BRASIL. Ministério da Fazenda, Secretaria do Tesouro Nacional, Instrução Normativa n. 04, de 30 de agosto de 2004. Disponível em: $<$ <ttp://manualSIAFI.tesouro.fazenda.gov.br>. Acesso em Dez./Jan.2008 e Fev.2009.

BRASIL. Ministério da Fazenda, Secretaria do Tesouro Nacional, Manual SIAFI Web. Disponível em: <http://manualSIAFI.tesouro.fazenda.gov.br>. Acesso em Dez./Jan.2008 e Fev.2009. 
APÊNDICE A - Questionário Aplicado

I. Com relação aos ingressos de recursos em moeda estrangeira como se dá:

1) O Processo de emissão de títulos/venda de ações no mercado externo?

2) O Processo de empréstimos de organismos internacionais e agências governamentais?

II. Com relação ao processo de transferência de recursos para a Conta Única do Tesouro, como ocorre?

III. Com relação às liberações para pagamento de despesa no exterior, como ocorre:

3) O contrato com Instituição Financeira (IF)?

4) O pagamento de pessoal e de custeio?

5) O pagamento efetuado para organismo internacional em referencia aos projetos financiados por organismos Internacionais?

6) Existem outros tipos de pagamento?

IV. Em relação ao SIAFI, existem restrições quanto à:

7) Criação de contas contábeis em moeda estrangeira e respectiva disponibilidade por fonte?

8) Há necessidade de revisão do decreto de programação financeira ou de outros procedimentos para criação da conta de limite de saque em moeda estrangeira?

9) Estabelecer que a moeda estrangeira para as movimentações seja o Dólar?

10) Criação da Ordem Bancária de Movimentação de Reservas em Moeda Estrangeira?

V. Quanto ao Sistema Brasileiro de Pagamentos do Banco Central e no relacionamento da STN com o Banco do Brasil quais as dificuldades para:

11) Adequação do catálogo de mensagens?

12) Adequação do Piloto do SOTN?

13) Definição do BB como Instituição Financeira conveniada para pagamento no Exterior?

14) Estabelecimento de forma padrão de fechamento de câmbio? 
APÊNDICE B - Objetivos do Questionário Aplicado

\begin{tabular}{|c|c|}
\hline Pergunta & Objetivo \\
\hline 1 e 2 & $\begin{array}{l}\text { Conhecer como se dá na pratica o processo para avaliar a pertinência à } \\
\text { legislação e posssibilidades de estabelecimento de tipo de depósito } \\
\text { direto na Conta Única. }\end{array}$ \\
\hline 3 & Entender o relacionamento, atribuições, competências e deveres da IF. \\
\hline 4 e 5 & Entender como ocorre e a forma de contabilizar no sistema SIAFI. \\
\hline 6 & Conhecer todos os tipos de pagamentos realizados no exterior. \\
\hline 7 & $\begin{array}{l}\text { Entender o escopo necessário de alterações na contabilidade do SIAFI } \\
\text { e o analisar os desdobramentos relacionados com a Lei Orçamentária } \\
\text { Anual (LOA) e a Lei de Diretrizes Orçamentárias (LDO). }\end{array}$ \\
\hline 8 & $\begin{array}{l}\text { Conhecer e avaliar os impactos no decreto de programação financeira, } \\
\text { com vistas ao entendimento das modificações necessárias. }\end{array}$ \\
\hline 9 & $\begin{array}{l}\text { Avaliar a pertinência e dificuldades no estabelecimento da moeda dólar } \\
\text { americano como moeda estrangeira para as movimentações. }\end{array}$ \\
\hline 10 & $\begin{array}{l}\text { Avaliar as necessidades de ajustes nos procedimentos contábeis para } \\
\text { criação de OBR em moeda estrangeira. }\end{array}$ \\
\hline 11 & $\begin{array}{l}\text { Avaliar necessidade de criação de mensagem SPB específica para os } \\
\text { casos de pagamento no exterior e elaboração de comunicado junto ao } \\
\text { BACEN para reunião do GT-Mensagem. }\end{array}$ \\
\hline 12 & $\begin{array}{l}\text { Entender as necessidades de ajustes no sistema. } \\
\text { Avaliar necessidades de ajustes nos processos de conciliação bancária } \\
\text { do SIAFI junto ao BB. }\end{array}$ \\
\hline 13 & $\begin{array}{l}\text { Avaliar as dificuldades e caminhos possíveis que permita ao BB ser a } \\
\text { única IF definida para atuar no exterior em atendimento às } \\
\text { necessidades das Unidades Gestoras fora do Brasil. }\end{array}$ \\
\hline 14 & $\begin{array}{l}\text { Entender o mecanismo atualmente adotado para fechamento de } \\
\text { câmbio e a avaliação das dificuldades para adoção de mecanismo } \\
\text { padrão e integrado das necessidades de câmbio no atendimento da } \\
\text { programação de pagamento das despesas no exterior. }\end{array}$ \\
\hline
\end{tabular}




\section{APÊNDICE C - O sistema Swift}

As relações internacionais e as relações interbancárias pautam-se por uma estreita e intensa relação que vai além fronteiras. Por isso o setor bancário está no topo da cadeia de desenvolvimento de sistemas de informação.

Inicialmente a comunicação interbancária era realizada por carta, telegrama e telex, meio totalmente ultrapassados e que não garantiam confidencialidade, segurança e rapidez indispensável aos dias de hoje.

O SWIFT é um sistema adotado internacionalmente, que visa estabelecer e manter a comunicação entre os diversos bancos. Constitui-se numa rede de comunicação para atender às necessidades das instituições no estrangeiro para realização de transações financeiras rápidas e seguras.

Esta rede surgiu em 1970, agrupando inicialmente apenas sete países. Atualmente expande-se por todos os continentes, abrangendo milhares de instituições bancárias.

Em termos práticos o SWIFT constitui uma sociedade cuja finalidade é facilitar a troca de mensagens relativas a operações bancárias, em todo o mundo, No sentido de otimizar e facilitar a comunicação, o sistema SWIFT padroniza as mensagens mais usuais que correspondem a algumas das operações mais comuns efetuadas em moeda estrangeira. Entre outras operações, destacam-se:

- As transferências entre clientes e ordens de pagamento;

- As transferências entre bancos;

- Os câmbios e os depósitos;

- As cobranças e as remessas;

- Os títulos;

- Os créditos documentários;

- Os extratos e confirmações de débito ou crédito.

Os bancos se constituem como os clientes de toda esta rede de comunicações. São emissores ou receptores de mensagens. A rede de comunicação SWIFT engloba uma série de vantagens que a tornam preferível a outras formas de comunicação interbancária, tais como:

\begin{tabular}{|l|l|}
\hline Flexibilidade & $\begin{array}{l}\text { Uma mensagem SWIFT pode ser } \\
\text { transmitida em simultâneo a mais de um } \\
\text { banco. }\end{array}$ \\
\hline
\end{tabular}




\begin{tabular}{|l|l|}
\hline Segurança & $\begin{array}{l}\text { Todas as operações são registradas, com } \\
\text { mensagens autenticadas. }\end{array}$ \\
\hline Facilidade de consulta & $\begin{array}{l}\text { A obtenção de dados sobre as operações } \\
\text { realizadas é simples. }\end{array}$ \\
\hline \hline Rapidez & $\begin{array}{l}\text { Em poucos segundos, uma mensagem } \\
\text { chega de um continente a outro. }\end{array}$ \\
\hline
\end{tabular}


APÊNDICE D - Controle Interno

As atividades de controle devem ser exercidas em todos os níveis e através não só de um órgão específico, mas também das chefias competentes. A coordenação dessas atividades no Poder Executivo está legalmente atribuída à Secretaria Federal de Controle Interno do Ministério da Fazenda (SFC/MF), órgão integrante do Sistema de Controle Interno do Poder. O Sistema de Controle Interno do Poder Executivo Federal tem as seguintes finalidades:

- Avaliar o cumprimento das metas previstas no Plano Plurianual, a execução dos programas de governo e dos orçamentos da União;

- Comprovar a legalidade e avaliar os resultados, quanto à eficácia e à eficiência, da gestão orçamentária, financeira e patrimonial nos órgãos e nas entidades da Administração Pública Federal, bem como da aplicação de recursos públicos por entidades de direito privado;

- Exercer o controle das operações de crédito, avais e garantias, bem como dos direitos e haveres da União;

- Apoiar o controle externo no exercício de sua missão institucional.

Além de serviço de suporte às atividades de controle externo, ao controle interno cabem as tarefas de avaliação do cumprimento das metas previstas no PPA e da execução dos programas de governo e dos orçamentos da União, consoante o disposto no art. 74, da Constituição Federal, que prevê que a verificação da legalidade dos atos de execução será prévia, concomitante e subseqüente. 


\section{APÊNDICE E - Controle Externo}

O controle externo é exercido pelo Congresso Nacional com o auxílio do Tribunal de Contas da União - TCU, e compreende, dentre outras atividades, a apreciação das contas do Presidente da República, o julgamento das contas dos administradores e demais responsáveis por bens e valores públicos, bem como a legalidade dos atos de admissão de pessoal, a qualquer título. O TCU é responsável pelas funções de auxiliar o Congresso Nacional na atividade de controle externo, apresentando Relatório e Parecer Prévio sobre as contas do Presidente da República e julgando a regularidade das contas dos administradores e demais responsáveis por bens e valores públicos.

O Presidente da República deverá remeter ao Congresso Nacional, dentro de sessenta dias após a abertura da sessão legislativa, as contas relativas ao ano anterior. O Congresso Nacional, por sua vez, encaminhará ao TCU as contas do Presidente, acompanhadas de demonstrativos elaborados pela STN, para que 0 Tribunal elabore um Relatório e Parecer Prévio sobre as contas. O TCU tem sessenta dias para elaborar e encaminhar o parecer ao Congresso Nacional, que deverá apreciar as contas dos Três Poderes da União, valendo-se, fundamentalmente, dos seguintes documentos: Balanço Geral da União, Relatório e Parecer Prévio do TCU, além do relatório e voto da Comissão Mista de Planos, Orçamentos Públicos e Fiscalização do Congresso Nacional. 
APÊNDICE F - A elaboração e a execução dos orçamentos públicos

A Constituição Federal de 1988 criou três leis em sentido formal (lei ordinária) que compõem o sistema orçamentário brasileiro:

Plano Plurianual: Uma das três leis em sentido formal (lei ordinária) que compõem o sistema orçamentário brasileiro. Estabelece de forma regionalizada as diretrizes, objetivos e metas da administração pública federal para as despesas de capital e outras delas decorrentes e para as relativas aos programas de duração continuada. Vigora por quatro anos, sendo elaborado no primeiro ano do mandato presidencial, abrangendo até o primeiro ano do mandato seguinte. Está previsto no art. 165 da Constituição Federal.

Lei de Diretrizes Orçamentárias: de duração de um ano, define as metas e prioridades do governo para 0 ano seguinte, orienta a elaboração da lei orçamentária anual, dispõe sobre alterações na legislação tributária e estabelece a política das agências de desenvolvimento. Também fixa limites para os orçamentos dos Poderes Legislativo e Judiciário e do Ministério Público e dispõe sobre os gastos com pessoal.

Lei Orçamentária Anual: estima a receita e fixa a despesa do exercício financeiro definindo como o governo vai arrecadar e como irá gastar os recursos públicos.

A LRF remeteu à LDO diversos outros temas, como política fiscal, contingenciamento dos gastos, transferências de recursos para entidades públicas e privadas e política monetária.

Proposta de Lei Orçamentária Anual (PLOA) elaborada pelo Executivo segue um procedimento que pouco se altera de um ano para o outro. A SOF estima as receitas e despesas de cada ministério (pessoal, contribuições previdenciárias, dívidas etc.), do Legislativo e do Judiciário e define os parâmetros das demais despesas, inclusive operacionais e de investimentos e os limites de despesas para cada programa que cada um dos órgãos públicos se propõe a desenvolver. Isto não significa que é feita uma reavaliação de todas as despesas. O que normalmente acontece é o incremento de despesas já existentes. Os Órgãos envolvidos no processo orçamentário são:

- Ministério do Planejamento, Orçamento e Gestão

Secretaria de Orçamento Federal (SOF) 
Secretaria de Investimentos e Planejamento Estratégico (SPI)

Departamento das Estatais (DEST)

- Ministério da Fazenda

Secretaria do Tesouro Nacional (STN)

Secretaria da Receita Federal (SRF)

Secretaria de Política Econômica - SPE

- Congresso Nacional

Comissão Mista de Orçamentos (CMO)

Consultoria de Orçamentos do Senado (CONORF)

Consultoria de Orçamentos da Câmara (COFF)

- Tribunal de Contas da União

Esse processo se deve ao fato de que a maioria das receitas é vinculada a despesas por força de lei, uma prática que se iniciou com a própria CF de 1988, por meio do princípio da não-afetação da receita pública, vinculando receitas para despesas da saúde e da educação e dessa forma, excluindo-se as despesas obrigatórias, sobre muito pouco para as demais despesas. Isso impõem forte rigidez ao orçamento.

Durante o período de apreciação para votação esse pouco recurso será alvo de modificações. Despesas canceladas (total ou parcialmente) e re-estimativas de receitas montam o que é conhecido por "cesta de recursos". Nascem as "emendas" e a disputa pelo uso dos recursos da "cesta de recursos". Assim, recebido pelo Congresso Nacional, o projeto é publicado e encaminhado à Comissão Mista de Planos, Orçamentos Públicos e Fiscalização - CMO. A Resolução №. 01, de 2006 $\mathrm{CN}$ regula a tramitação legislativa do orçamento. A CMO realiza audiências públicas e nessa oportunidade os parlamentares começam a avaliar a proposta apresentada e têm a possibilidade de ouvir tanto as autoridades governamentais como a sociedade.

O parlamentar designado para ser o relator-geral da PLOA deve elaborar Relatório Preliminar que é composto de duas partes:

- Primeira parte com análise das metas fiscais, exame da compatibilidade com o PPA, a LDO e LRF, entre outros temas;

- Segunda parte com as regras para a atuação dos relatores setoriais e geral e orientações específicas referentes à apresentação e apreciação de emendas, inclusive as de relator. Define, também, a composição da Reserva de Recursos (cesta de recursos) a ser utilizada para 0 
atendimento das emendas apresentadas.

As emendas à despesa são classificadas como de remanejamento que propõe acréscimo ou inclusão de dotações e, simultaneamente, como fonte exclusiva de recursos, a anulação equivalente de dotações constantes do projeto, exceto as da Reserva de Contingência. Com isso, somente poderá ser aprovada com a anulação das dotações indicadas na própria emenda, observada a compatibilidade das fontes de recursos, de apropriação que propõe acréscimo ou inclusão de dotações e, simultaneamente, como fonte de recursos, a anulação equivalente de valores da Reserva de Recursos ou outras dotações definidas no Parecer Preliminar ou de cancelamento que propõe, exclusivamente, a redução de dotações constantes do projeto.

As bancadas estaduais no Congresso Nacional e as comissões permanentes do Senado Federal e da Câmara dos Deputados podem apresentar emendas ao projeto nas matérias diretamente ligadas às suas áreas de atuação. Cada parlamentar pode apresentar até 25 emendas individuais, no valor total definido pelo Parecer Preliminar. Os relatores somente podem apresentar emendas para corrigir erros e omissões de ordem técnica e legal, recompor, total ou parcialmente, dotações canceladas e atender às especificações do Parecer Preliminar.

A PLOA é divida em 10 áreas temáticas e para cada área temática é designado um relator setorial, que deve avaliar o projeto encaminhado, analisar as emendas apresentadas e elaborar relatório setorial com as suas conclusões e pareceres.

Após a aprovação dos relatórios setoriais, é tarefa do Relator Geral compilar as decisões setoriais em um único documento, chamado Relatório Geral, que será submetido à $\mathrm{CMO}$. O papel do relator geral é verificar a constitucionalidade e legalidade das alocações de recursos e zelar pelo equilíbrio regional da distribuição realizada.

O relatório aprovado em definitivo pela Comissão constitui o parecer da $\mathrm{CMO}$, o qual será encaminhado à Secretaria-Geral da Mesa do Congresso Nacional, para ser submetido à deliberação das duas Casas, em sessão conjunta.

Concluída a votação, a matéria é devolvida a CMO para a redação final e o texto aprovado definitivamente e assinado pelo Presidente do Congresso é enviado à Casa Civil da Presidência da República para sanção.

As emendas integram o orçamento público brasileiro autorizativo, mas não 
garantem por si só o atendimento. Uma coisa é ter a despesa no orçamento, outra é poder executar essa despesa. Depois de aprovado o orçamento, outras barreiras devem ser transpostas para a execução da despesa, tais como:

- Limite de Empenho;

- Contingenciamento;

- Programação Financeira;

- Metas Fiscais;

- Limite de Pagamentos;

- Fatores externos como modificação do comportamento do Dolar e etc. 
ANEXO A - Artigo "A cultura do poço sem fundo"

O Texto "Quando assumi a presidência, não era possível calcular o déficit nem avaliá-lo com margem de segurança". O Tesouro não existia assim como o conhecemos hoje. Era uma entidade abstrata. Sem automação, sem controle em tempo real. O Ministério da Fazenda não tinha condições de avaliar a necessidade de qualquer liberação de recursos e o gasto das parcelas anteriormente liberadas. Existiam milhares de contas espalhadas pelo país, que pulverizavam os recursos públicos.

O exótico relacionamento do Tesouro com o Banco do Brasil (Conta de Movimento, que acabamos) e o Banco Central não permitia nenhuma transparência. Esses bancos executavam operações de caráter eminentemente fiscal, programas de fomento, colocação e resgate de títulos da dívida mobiliária etc. Era o Banco do Brasil a autoridade monetária e banco comercial. Essas operações constituam o chamado Orçamento Monetário, que corria por fora.

Uma das vantagens do Plano Cruzado foi criar as condições políticas para a modernização das contas públicas do país.

Em 10 de março de 86, pelo decreto 92.452, criamos a Secretaria do Tesouro Nacional, com a função de órgão central do sistema de administração financeira, contabilidade e auditoria do governo federal. Em dezembro de 86, o decreto 93.872 estabeleceu o "Caixa Único". Os decretos 93.874 e 93.878 estabeleceram o controle interno do Poder executivo e as normas de execução orçamentária da União, sistema hoje conhecido como SIAFI, que foi, pouco a pouco, implementado."

Iniciado o processo com Funaro e Andréa Calabi, teve em Maílson um executor firme e apaixonado, já que sua velha experiência e conhecimento do MF sonhavam sempre em realizar essa tarefa. Mas para que ela fosse executada era necessária a firmeza do presidente, pois essa tarefa importava em abdicar do poder político ilimitado que tinha o chefe do Executivo.

Quando a Constituição de 88 chegou, já encontrou essa mecânica implantada. Foi uma tarefa das mais importantes realizadas na administração do país. Mudou o primitivismo institucional existente.

Em 87 fizemos mais três decretos que visavam: 1) acabar com a função fomento do Banco Central, abrindo caminho para sua independência; 2) proibir e 
expansão da dívida pública, emissão e etc., somente autorizadas pelo Congresso Nacional; 3) consolidação final do orçamento que, pela primeira vez na história do Brasil, o de 1988, era unificado.

O velho sistema criou uma cultura. É essa cultura que o ministro Fernando Henrique quer enfrentar, de julgar-se a União aquela mina inesgotável de recursos ilimitados.

Lembremos que a C. F. redistribuiu recursos sem os ter e estrangulou a União. A Operação Desmonte, que formulamos, não foi aprovada. Clamei que, com isso, o país ia tornar-se ingovernável. Hoje, as vinculações chegam a $97 \%$ do Orçamento. Como governar? Pior ainda, abriu caminho para que se criasse um governo paralelo que assaltou a nação e a desmoralizou." 